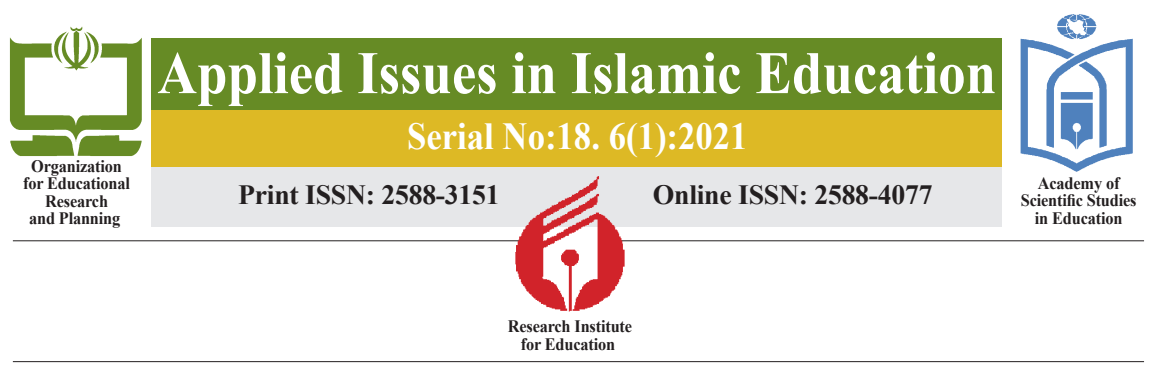

\title{
Validating the Talent Management Model of Elementary School Teachers in the Formal and Public Education System (Based on the Fundamental Reform Document of Education in the Islamic Republic of Iran)
}

\author{
- Leila Zahabion ${ }^{1}$ "Narges Saedian ${ }^{2}$-Narges Keshti arai ${ }^{3}$
}

- Objective: The present study aimed to validate the talent management model of elementary school teachers in Iran, and determine its fitness.

- Method: The study was done by a combined exploratory method in the academic year 2019-2020. In the qualitative phase of the study, the research method was deductive content analysis, in which 5 comprehensive themes of identification, recruitment, selection, employment, development and maintenance were extracted, and then according to the comprehensive themes, 10 organizing themes: identifying elite people, motivating to recruit elites, fitting a person to a job, electing qualified people, fully utilizing the capabilities of people, providing performance conditions, increasing individual knowledge, improving job and professional skills, teachers' excellence and well-being, and integrating people with the job of a teacher, and 40 basic themes were extracted. After confirmation of the validity and reliability, through the opinions of experts and specialists in educational sciences, in the quantitative part of the study, a descriptive-survey method was used to developing a questionnaire. The statistical population consisted of a small number of elementary school principals, deputies, and experts from education departments: experts of the elementary education, human resource promotion, administrative affairs, in education departments and the experts at the Farhangian universities. The sample size was 377 people who were selected based on the table of Cohen et al. by multi-stage random sampling method. After confirmation of the validity of the questionnaire and the obtained reliability (0.74), through Cronbach's alpha, the modeling method of covariance-based structural equations was used to validate the research model.

- Findings: All themes with high factor loading were confirmed, which indicated that the validity and reliability of the model was high.

- Conclusion: The implementation of this model can facilitate the realization of the goals of education in finding, recruiting and maintaining elite and effective people.

Keywords: talent management, elementary school teachers, education

Citation: Narges Saedian, Leila Zahabion, Narges Keshti arai.(2021). Validating the Talent Management Model of Elementary School Teachers in the Formal and Public Education System of Iran Based on the Fundamental Reform Document of Education in the Islamic Republic of Iran, Applied Isuues in islamic Education, 6(1):73-98.

Received: $2020 / 02 / 20$

Accepted: 2021/05/21

1. Ph.D. Student in Educational Management, the Faculty of Educational Sciences and Psycholoy, Isfahan Branch (Khorasgan), Islamic Azad University, Isfahan, Iran.

E-mail: bluesky_lz@yahoo.com. (IDID:https://orcid.org/0000-0001-9851-8542

2. Corresponding Author: An Assisstant Professor in Educational Management, the Faculty of Educational Sciences and Psycholoy, Isfahan Branch (Khorasgan), Islamic Azad University, Isfahan, Iran. E-mail: nsaeidian@yahoo.com. IDID:https://orcid.org/0000-0002-7389-3300

3. An Associate Professor in Curriculum Planning, the Faculty of Educational Sciences and Psychology, Isfahan Branch (Khorasgan), Islamic Azad University, Isfahan, Iran.

E-mail: keshtiaray@gmail.com. IDID:https://orcid.org/0000-0001-6313-5197 


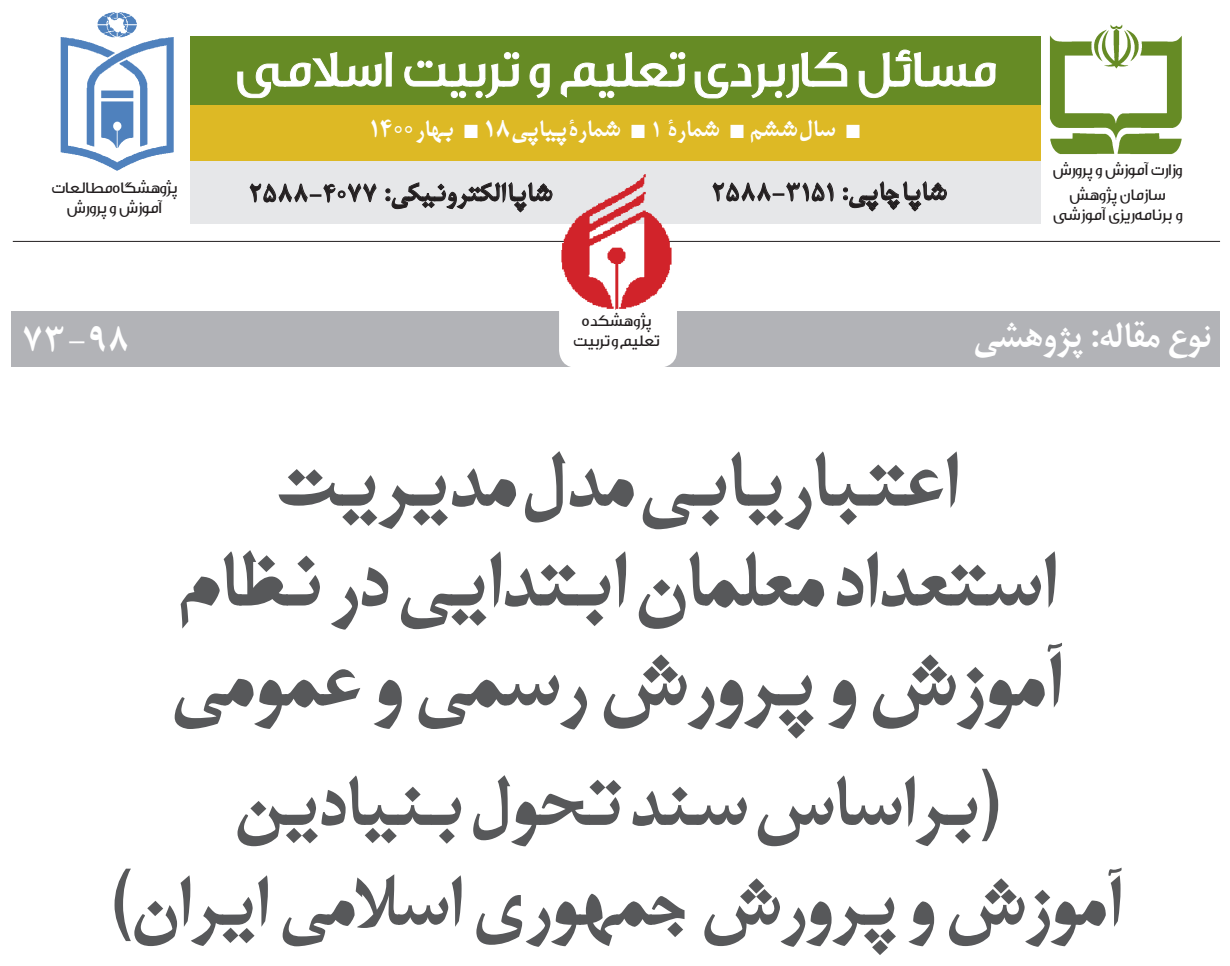

نركس كشتى آراى

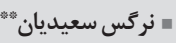

" ليلا ذهبيون"

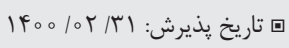

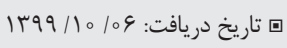

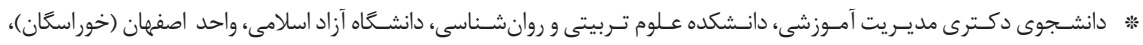

E-mail: bluesky_lz@yahoo.com. (D) 0000-0001-9851-8542

اصفهان، ايران.

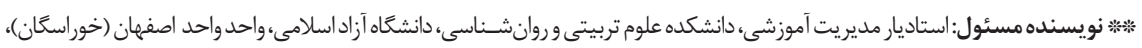

E-mail: nsaeidian@yahoo.com. (D) 0000-0002-7389-3300

اصفهان،ايران. 


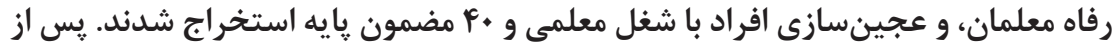

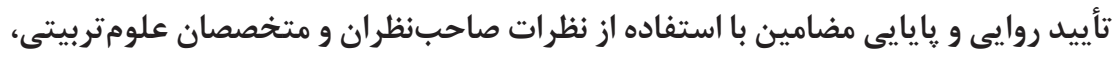

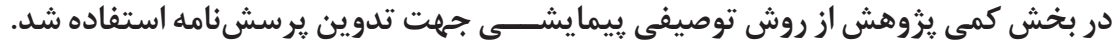

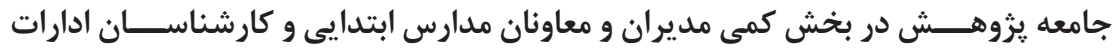

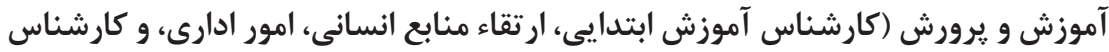

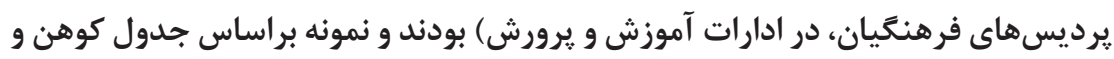

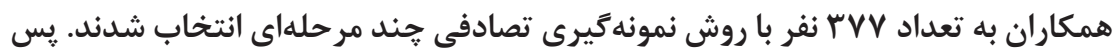

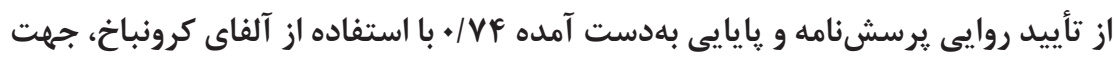

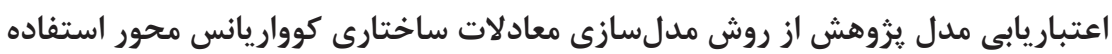
كرديد.

• يافتهها : همه مضامين با بار عاملى بالا مورد تأييد قرار كرفتند كه نشــــاندهنده روايـى و

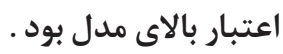

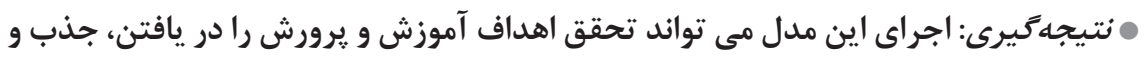

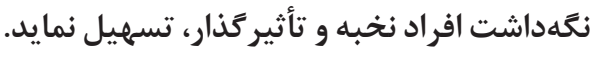

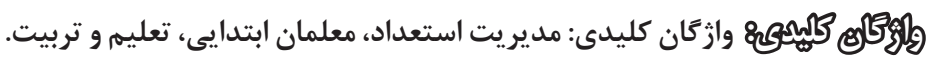

\section{مقامه}

بعىشــ عصر حاضر، عصر سازمانها است و متوليان ســازمانها انسانها هستند. انســانها عظيمترين منابع سازمانى هستند كه موجبات تعالى، پيشرفت، رشد و حركت

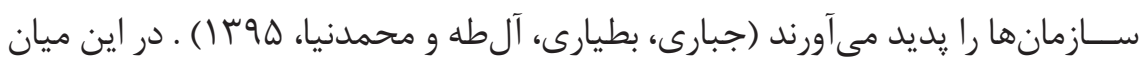
سازمانهاى آموزشــى بخش مهمى از سرمايه انسانى و توسعه اجتماعى و اقتصادى هر

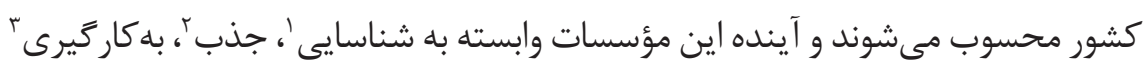

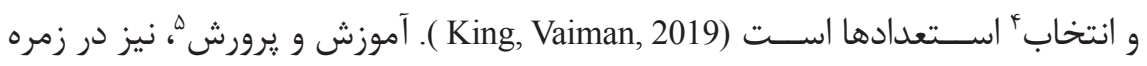
ســازمانهاى آموزشــى قرار دارد كه اصلىترين منبع آن انسانها هستند و براى پايدار ماندن در فضاى رقابتى و دستيابى به اهداف تعيين شده به مديريت استعداد نياز دارد

1. Identifying

2. Attracting

3. Recruithing

4. Selecting

5. Education

6. Talent management 
vr-91

تا بتواند اهداف تعيين شده در اسناد بالادستى از جمله سند تحول بنيادين' و انتظارات و نيازهـــاى جامعه را برآورده كند. آموزش و يـــرورش بهعنوان نهاد فرهنغى، اجتماعى، نقش اساســى و بى بديل در تربيت نيروى انسـانى و توليد سرمايه اجتماعى و فرهنگى و در فرآيند رشــد وتعالى كشور ايفا مى كند به كونهاى كه آينده كشور در آيينه آموزش و يرورش امروز قابل مشــاهده است (قديمى يرقودقى، حافظيان، 9 9 ()). نظام تعليهم و تربيت رسمى و عمومى در ايران وظيفه انتقال و توسعه فرهنگ در جامعه اسلامى ايران و آمــاده كردن دانشآموزان براى تحقق مرتبهاى از حيات طيبه در همه ابعاد را برعهده دارد و دســتيابى به اين مرتبه با وجود مربيان يا معلمان شايســــه اتفاق خواهد افتاد. سند تحول بنيادين (•وس () آموزش و يرورش، تعليم و تربيت را فرايندى تعالى جويانه، تعاملى، تدريجى، يكيارٌهه و مبتنى بر معيارهاى اسلامى مىداند و معلم فردى است كه

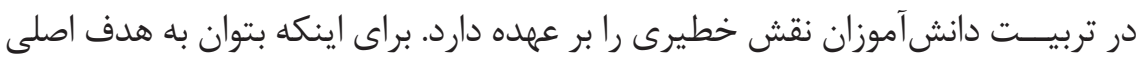
نظــام تعليمم و تربيت و نهادينه كردن شايســتخى ها در دانش آموزان دســت يافت، بايد معلمانى با شايســَى هاى لازم را شناسايى و انتخاب كرد سيس به كار زرفت و با توسعه آنها زمينه نكَهاشت معلمان شايسته را فراهم كرد. در مكتب اسلام و آيين ييامبران نيز كه نقش هدايت افراد را برعهده داشــتند اين جريان مديريتى ديده مىشود. در مكتب اســلام نيز مسئله شايستهسالارى و انتخاب شايسته ترين افراد جهت هدايت مسلمانان

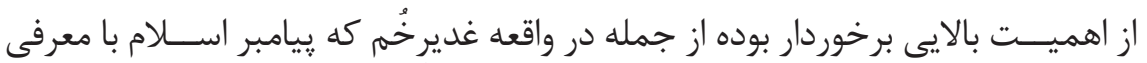
حضرت على(ع) درواقع دين مبين اسلام را كامل كرد. بنا به نقل ابن حجر دانشمند اهل

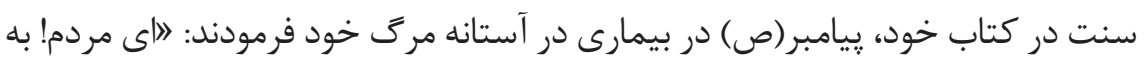
زودى به ديدار خدا مىشتابم و براى آنكه عذرى براى شما در كار نباشد، آخرين سخن را

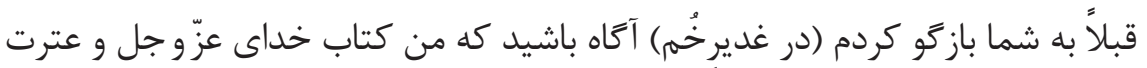
خود را در ميان شما بهجاى خود باقى مى گذارم و سيس دست على(ع) را گرفت و بلند كرد و فرمود: اين على(ع)، با قرآن اسـت و قرآن با اوســت و از يكديخر جدا نمى شوند تا

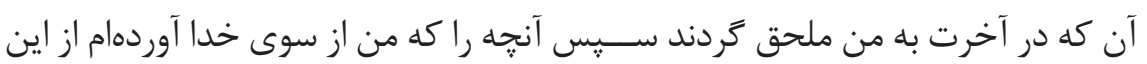

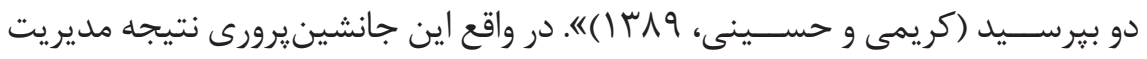
اســـتعداد ييامبر و شناسايى اســتعدادهاى امام على(ع) بود. مديريت استعداد در بخش 
آموزش اشـــاره دارد بهشناســايى و بهكار گيرى مربيان، معلمان و مديران اثربخش براى همه مدارس و كلاسهاى درس و تجهيز اين افراد به مهارتهاى آموزشى و رهبرى مورد نياز بهمنظور بهبود جشمخير موفقيت دانشآموزان (نصيرى و جهانيان، Vqس I). مربيان و معلمان بايد افراد مســتعد معلمى و مســلط به تعليم و تربيت اسلامى باشند. مربيان و معلمــان بايد ارزشهاو فضايل اخلاقى را در جنبههاى مختلف رشـــد دهند (انصارى، محسنى يور، 99 (1). مسئله شناسايى مربيانى باستعداد در سازمانهاى آموزشى بدان جهت از اهميت مضاعفى برخوردار اســت كه از برونداد ســازمانهاى آموزشى بهعنوان درونداد سازمانهاى ديخر استفاده مىشود. در سازمان هاى آموزشى هر جند بحث رقابت صنعتى مطرح نيست اما رقابت در زمينه جذب و نكَهدارى ' كاركنان مســـتعد و گرورش مهارتهاى آنان وجود دارد (نورادصديق،

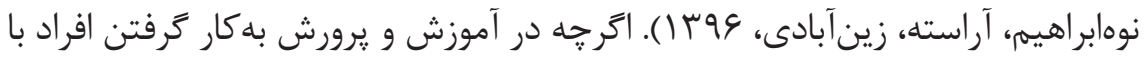
استعداد ضرورى است اما به تنهايى كافى نمىباشد، بلكه بايد روشهايى را به كار برد كه از توانايى افراد مستعد استفاده شود و تعهد اين افراد حفظ گردد (Davies \& Davies, 2010). مك دونل، كالينخز، ملاحى و اسكولر (McDonnell, Collings, Mellahi \& Schuler. 2017 ( مديريت اســتعداد را مجموعهاى از مانيفســتهاى ايدئولوزيك مديريتى در جهار حوزه اصلى جذب استعداد، مديريت عملكرد، برناملريزى جانشينيرورى و توسعه و نخَداشت كاركنان مى دانند. يس از شناســايى و جذب افراد باستعداد، نگَهداشت و ارتقاء آنها نيز اهميت ويزهاى دارد. امام على(ع) مىفرمايد : إيس زمينه را براى رســيدن آنها به آرمان خودشان (دستيابى به مسئوليت بالاتر و ابراز لياقت بيشتر) باز كنه إنى

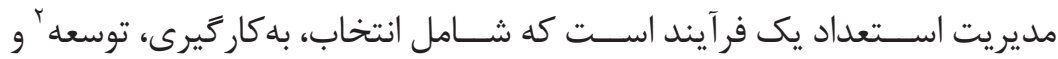
نخهداشت كاركنانى است كه داراى قابليتهاى راهبردى هستند و باعث موفقيت سازمان

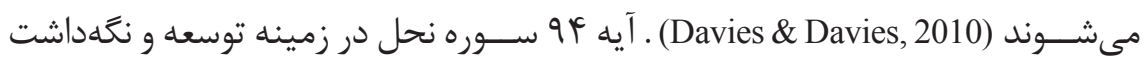
منابع انسانى بعد از بهكار گيرى مىفرمايد: و مانند آن ييرزن نباشيد كه رشته خود را يس

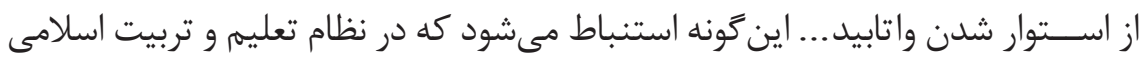
يس از به كاركيرى معلمان، آموزش و ارتقاء آنها از وظايف مديريت اسلامى است. قرآن در 
Vr-9A

آيه شريفه فوق از هر نوع كارى كه اساس و يايه متزلزلى داشته باشد و يس از انجام فرو ريزد نهى مى كند و تبعاً اين سعى و خطا در سازمانها بهد بهليل ماهيت توليدى، خدماتى آنها و ارتباطى كه با ســلامت آموزشــى، فرهنگىى، اقتصادى و... دارند داراى ييامدهاى مخربترى خواهد بود.

نتايج يزوهش ها از • • سازمان جهانى نشان داده كه همه آنها بامشكل ناتوانى در اجراى استراترى مديريت استعداد روبهروهستند كهنتيجه آن، كمبودنيروهاى مستعدبراى ير كردن يستهاى استراتزيك سازمانى مىباشد و همين امر بهطور قابلتوجهى توانايى سازمانها رابراى رشد، محدود ساخته است (Collings \& Mellahi,2007, Ready \& Conger.2009). سازمانها با توسعهُ ســـازمانى و يرورش افراد كه به ايجاد قابليتهايى مطابق جشهمانداز كمك مى كند، نياز دارند و در اين رابطه نيز مديريت اســتعداد مى تواند راهَشـــا باشد

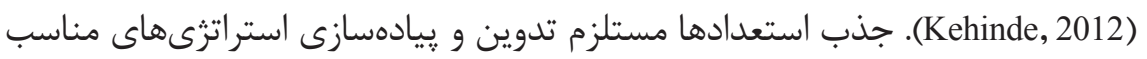
جذب اســت كه از طريق آن كمبود نيروهاى مســتعد براى ير كردن پستها و مشاغل كليدى و استراتزيك جبران شود. توصيه مىشود كه سازمانها روشهاى سنتى جذب را كنار كذاشته و استراتزىهاى خلاق جذب را بهكار گيرند تا بتوانند برترينها را جذب

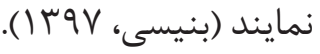
دوره ابتدايى اولين دورهاى اســت كه دانش آموزان به آن وارد مىشوند و در سيستم آموزشــى اهميت زيادى دارد جرا كه عملكرد معلمان در اين مقطع باعث رشد فراخيران و افزايش توانايى دانشآموزان مىشود. شناسايى، جذب، به كارگيرى، توسعه و نگَهداشت معلمان با استعداد براى اين مقطع، بهرهورى را به دنبال دارد (Smart \& Ebong, 2019). امروزه با تغييرات گسترده در نظامهاى آموزشى جهان، و به تبع آن تغييرات ايجاد شده در فراخيران، شناسايى، استخدام و به كارگيرى معلمان با استعداد از اولويتهاى آموزش و يرورش مى باشد. مسئولين آموزش و يرورش جهت كار آمدتر و اثر بخشتر كردن فعاليتهاى خود و همجٍنين تربيت نسل مستعد و آماده به كار براى جامعه مطابق شايستخى هاى ذكر

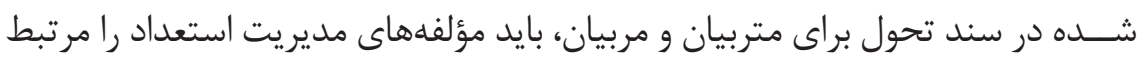

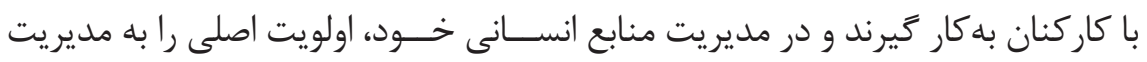
استعداد يرسنل بدهند. رايجترين مدل مديريت استعداد مدل (Philips \& Roper, 2009) مىباشـــد كه در اكثر يزوهشها آمده است و بسيارى از مدلهاى يزوهش بر اساس اين 
مدل طراحى شــده اند. استخدام و جذب افراد با استعداد در آموزش و يرورش براساس مدل مديريت اســتعداد باعث مىشود افرادى كه علاقه، استعداد و توانايى معلمى دارند جذب كار شــوند. در اين مرحله افراد با اســتعداد و با قابليتهاى معلمى و مديريتى در جايگًاه شـــلى مناسب قرار مى گيرند و تحقق اهداف نهاد تعليم و تربيت اتفاق مىافتد.

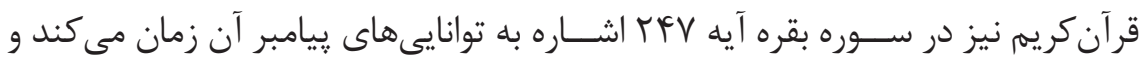
بركزيده شــدن وى را بر اساس اســتعدادها و توانايى هايى كه دارد مى داند نه بر اساس ثروت وى.

درواقع آنجه كه بهعنوان ضروريات سازمانهاى آموزشى در رابطه با مسئله مديريت اســـتعداد، وجود استعدادهاى متتنوع در انســان و لزوم يرورش آن بيان شد، موضوعاتى اســت كه در مبانى انسان شــناختى و فلسفه تعليمى و تربيت در جمهورى اسلامى ايران و همجنين در اســناد بالادســتى آموزش و يرورش كه آن نيز بركرفته از اصول تربيتى دين اسلام مى باشـــ، مطرح گرديده است؛ جنانجه هدف عملياتى دهم و يازدهم سند

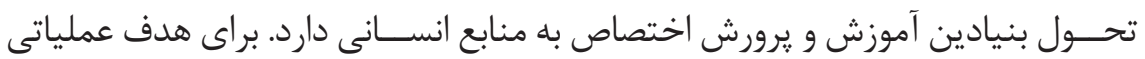
دهم لارتقاى منزلت اجتماعى جايگاه حرفهاى منابع انســانى با تأكيد بر نقش الكويى و جايگًاه معلم"، جهار راهكار بيان شده است. راهكار سوم \اصلاح قوانين و مقررات موجود استخدامى، مالى و ادارى متناسب با حرفههاى تخصصى با مشاركت دستخاههاى ذيربط مىباشــد. هدف عملياتى يازدهم اين سند البازمهندســى سياستها و باز تنظيهم اصول

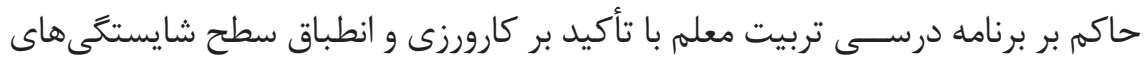

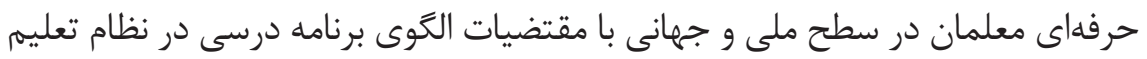
و تربيت و طراحى سياستهاى مناسب براى ارتقاى شيوههاى جذب، تربيت و نحَهاشت

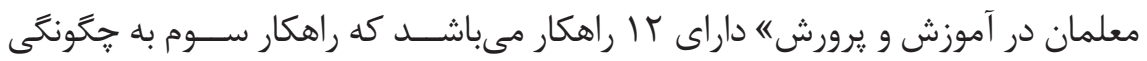
جذب و نگَهداشت اســتعدادهاى برتر و برخوردار از كليه صلاحيتها، و راهكار هفتم به توســـه زمينه يزوهشـــرى و افزايش توانمندىهاى حرفهاى به شكل فردى و گرووهى يرداخته اســت. هر دو هدف عملياتى ذكر شــده مربوط به هدف كلان جهارم ابرقرارى

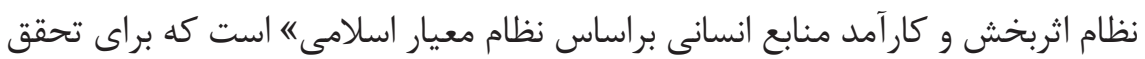
اين هدف نياز به مديريت استعداد است تا مؤلفههاى استخدام، جذب، تربيت، نخهداشت و ... به شـــكل صحيح و براساس شايســتخى اتفاق افتد. از طرفى سومين زيرنظام اصلى 
$v r-91$

در مبانــى نظرى تحول بنيادين آموزش و يرورش، تربيت معلم و تأمين منابع انســانى است. اين زيرنظام شامل جذب، آمادهسازى، حفظ، ارتقاء و ارزشيابى معلم و ساير منابع انســانى است و در بر گيرنده تمام افراد از ســطح ستاد تا سطح مدرسه است. اصول اين زيرنظام بيان مى كند كه سياستهاى حاكم بر جذب و تربيت منابع انسانى بايد از تنوع كافى برخوردار باشد و منجر به تأمين و ذخيرهسازى منابع انسانى شده و امكان انتخاب افرادى كه داراى صفات، توانمندىهاى جسمى و ذهنى، دانش و مهارت حرفهاى سطح بالا هســـند را فراهم نمايد. در اصول مؤلفه حفظ و ارتقاء مربيان لاتدوين سياســتها و برنامههايى براى رشــد حرفهاى معلمان و واكذارى مســـئوليتهاى مديريتى در سطوح مختلف به افراد براســاس شايستخى هاى حرفهاى و تجربه" مطرح شده است. همجنين هدف عملياتى يانزدهم - راهكار سوم و :جهارم به مديريت استعداد دانش آموزان و معلمان يرداخته است. راهكار ساه إ: شناســايى اســتعدادهاى برتر و هدايت آنها به ادامه تحصيل در

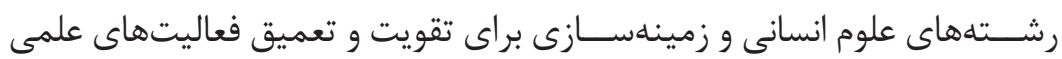
يزوهشى آنها در دورههاى آموزش عالى. راهكار F-1ها: جذب و تربيت معلمان مســتعد، آكاه و متعهد براى تدريس در درسهاى علوم انسانى، دانش افزايى مستمر معلمان در حين خدمت و ارتقاى شأن

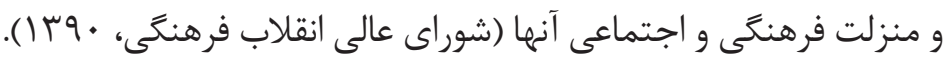

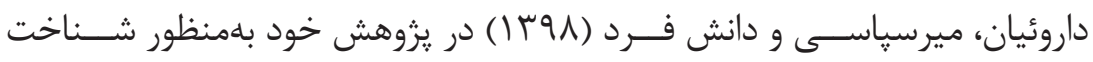
مؤلفه هاى وضع موجود و مطلوب مديريت استعداد و فاصله بين آنها و طراحى مدل بهينه مديريت استعداد در ميان مدرسين دانشگاه به اين نتيجه رسيدند كه بين وضع مطلوب و وضع موجود مديريت استعداد فاصله وجود دارد، براساس يافتههاى يثوهش، مديريت

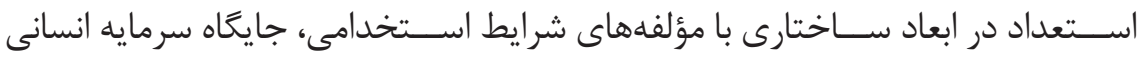

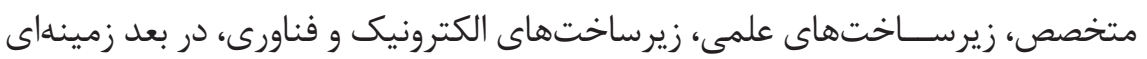

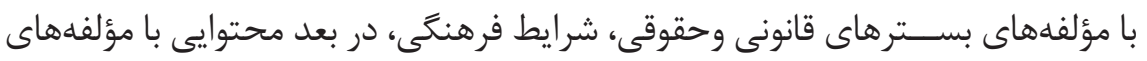
يذيــرش و حمايت مديـــران، يذيرش و حمايت مدرســـين، داراى فاصله وضع موجود و مطلوب بيشترى نســبت به ساير مؤلفههاى بررسى شده داشت. براساس اين بررسىها،

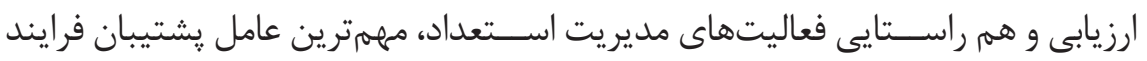


مديريت استعداد مى باشد و قدرت اين مدل در انسجام و يكيارجّگى يوياى قابليتهاى شناســايى، كشف، جذب، توسعه، حفظ و نكَهدارى و به كارگيرى اثربخش استعداد و هم راستايى اين قابليتها با استراتثى كلى دانشعاه، نهفته است.

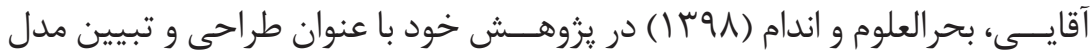
فر آيند مديريت اســتعداد معلمان تربيت بدنى به اين نتيجه دستيافتند كه مؤلفههاى فر آيند مديريت اســتعداد معلمان تربيت بدنى كثــور، در رِنج بُعد استراترى سازمان،

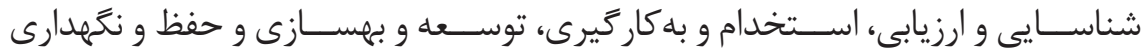
استعدادها دستهبندى شدند. در نهايت، بررسى و آزمون مدل مفهومى يزوهش نشان داد شاخصهاى كلى برازش مدل در وضعيت مناسب و مطلوبى قرار دارند.

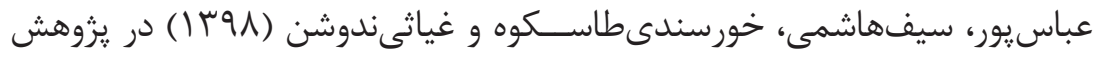
خود با عنوان تدوين و اعتباريابى الگوى مديريت استعداد، اين الگو را در مدارس دانشگاه آزاد اسلامى (سما) در قالب و بعد و 19 متغير اندازه يذير ارائه دادند كه عبارتند از: ا. شناسايى و جذب پرت كليدى (مديران سازمان ومديران مدارس)؛ r. عوامل شناخت فرد مستعد (قابليت - مهارت تعهد)؛ ". عوامل انتخاب فرد مستعد (مصاحبه وآزمون- بررسى رزومه كارى)؛

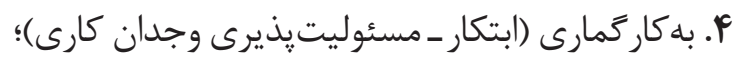
ه. توسعه (توانمندسازى، ييشرفت مسير شغلى، آموزش ضمن خدمت، ارزيابى)؛ צ. نگهداشت (سيستم جبران خدمتـ توجه به نيازهاى مادى و معنوى). براى اعتباريابى الكوى پيشنههادى از روش معادلات ساختارى و تحليل عاملى تأييدى استفاده شد. نتايج تحليل عاملى تأييدى نشان داد كه 9 مولفه شناسايى شده داراى بار عاملى معنى دار و نشان از برازش مطلوب ومناسب دارند. تر كاشوند، كشاورز، صالحى، ميرزامحمدى (Y (I ) به مبانى معرفتشناسى عدالت از ديـــدَاه فارابى يرداختند. در بعد حكمت از جالشهاى عدالت تربيتى توجه نكردن به يرورش استعدادها مطرح شده است. توجه به استعداد و شايستخى از اصول عدالت تربيتى و يرورش اســتعدادها از روشهاى عدالت تربيتى اســت. در واقع شتاسايى جالشهاى عدالت تربيتى مثل توجه نكردن به اســتعداد كه با روش تربيتى رشد و يرورش استعداد از بين مى رود. 
vr-91

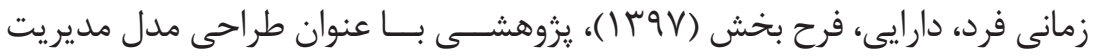
اســـعداد معلمان درنظام آموزش و يرورش انجام دادند؛ جامعه آمارى شــامل خبر گان

يعنى افراد داراى ســابقه تدريس در حوزه مديريت استعداد، افراد داراى كتب و مقالات مرتبط، افراد داراى ســابقه كار در وزارت آموزشويرورش و سازمانهاى آموزشويرورش استانها در حوزه مديريت استعداد و همرجنين آموز گاران آكاه در زمينه مديريت استعداد بودنـــد كه بهروش نمونه گيرى هدفمند بهعنوان نمونه انتخاب گرديدند و مورد مصاحبه نيمه ساختاريافته قرار گرفتند. براساس تحليل دادههاى حاصل از مصاحبهها، ب F شاخص اســتخراج گرديد. در مرحله بعد يرسشنامه بسته ياسخ براساس شاخصهاى حاصل از مصاحبهها و شاخصهاى مستخرج از ادبيات و ييشينه يثرهش (r شاخص) بر مبناى طيف هفتدرجهاى ليكرت با ع • أ ₹ويه طراحى و تدوين گَرديد و طى سه راند در اختيار خبر ₹ان قرار ₹رفت. در يايان هر راند دادههاى بهدستآمده با استفاده از ميانگين رتبهاى و ضريب توافق كندال تحليل شدند. نتايج محاسبه ضريب توافق كندال در یايان راند سوم نشــان داد جون مقدار بهدستآمده براى آماره آزمون كندال (ه •/V/•) در سطح خطاى

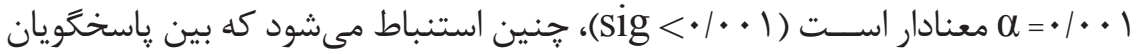
در ارتباط با ســؤالات توافق معنادار وجود دارد و مقدار بهدســتآمده برى آماره كندال حاكى از اتفاقنظر قابلقبول بين ياسخگويان است بنابراين در راند سوم مرحله كيفى به

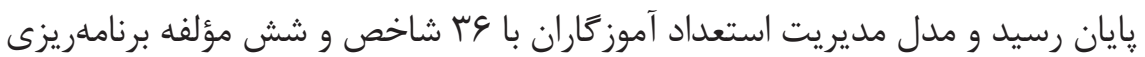
استراتزيك، شناسايى، گزينش، جذب، بهسازى و نَّهدارى گيديدار شد.

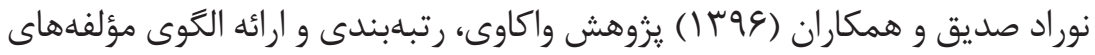
شناســايى مديران مستعد مدارس غيردولتى شهر تهران را با روش آميخته انجام دادند. جامعه يزووهش در بخش كمى مؤسســان و مديران مدارس متوســـهـ غيردولتى تهران بود. يس از بررسى دادهها، در بين سا مؤلفه، مهارت ظرفيتسازى، ويزگَىهاى اخلاقى، اشتياق، مهارتهاى فردى و بين فردى در اولويت اول قرار دارد. سا مقوله كلى شناسايى شده براى فرايند مديريت استعداد عبارت بود از: شرايط علمى (بلوغ سازمانى و ساختار

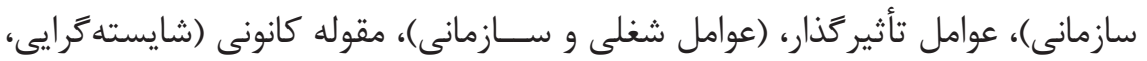
راهبردهاى مديريت اســتعداد آموزش كاركنان، طرحريزى اجراى مديريت اســتعداد، تمركززدايى)، عوامل زمينهاى (مشــار كت معلمان، ساختار نظاممند، امكانات آموزشى)، 
شـــرايط مداخله گر (اســـتقلال مدارس)، و ي يامدها (بالندگى سازمانى). نشانگان توسعه مديران با اســتعداد شــامل برنامهريزى مدون براى توسعه (نيازسنجى و آموزش و ارائه مناســب)، ايجاد شـــرايط انتقال اثربخش اطلاعات، كمك كرفتــن از اولياى زبده براى انتقال اطلاعات به مديران، كمك گرفتن از اساتيد دانشخاه براى انتقال مؤثر اطلاعات به مديران، اختصاص شرح وظايف مدير مدرسه به مسائل آموزشى، فراهم آوردن تسهيلات براى بلروزآورى اطلاعات، فراهم آوردن امكانات ييشـــفت علمى، ارائه مشاوره آموزشى، ياد گيرى مســـتمر، برَزارى دورههاى تخصصى متناســب با توانايى هر فرد و بيشترين تأكيد بر ايجاد فرصت توسعه شغلى است.

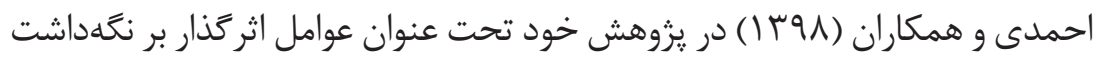
معلمان نخبه و مســتعد در دوره دوم متوســــهُ مدارس دولتى آموزش و يرورش شهر

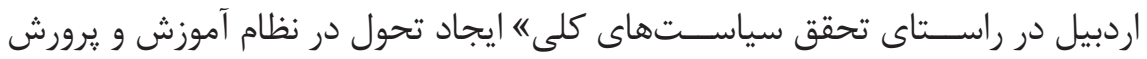
اببه اين نتيجه دســتيافتند كه عوامل مؤثر بر نخهداشت استعداد در دوره دوم متوسطه آموزش و يرورش شـــهر اردبيل به دو دسته عوامل ســازمانى و شغلى تقسيم مىشوند. عوامل ســازمانى شامل كار تيمى، فرهنَـسازمانى، فراهمآورى فرصت رشد و شكوفايى، مديريت اطلاعات و ارتباطات، جوّ ســازمانى، توانمندسازى، آموزش و بهسازى، رهبرى مدرســـه، مديريت عملكرد، نيازسنجى آموزشى، ماموريت و جشمانداز شفاف، قدردانى و تشويق و عوامل شغلى شامل وجههُ شغل، خشنودى شغلى، تناسب شغل و شاغل، يويايى شغل وكيفيت زندگى كارى مىباشد. شناســايى مؤلفههاى مديريت بهينه اســتعداد در دانشخاه علوم يزشكى بجنورد از ديدگاه كاركنان توسط جبارى و همكاران (هوس (1) بهروش نمونه با يرسشنامه محقق ساخته انجام شد. يس از تحليل دادهها، نتايج تحليل عاملى نشان داد كه ينـج مؤلفه جذب، انتخاب، توســعه، عجين شــدن با كار، و نَخهدراى اســتعداد با مديريت اســتعداد رابطه معنادار دارد و همجنين نشـــان داد كه نتخهدارى استعداد سيس انتخاب سيس توسعه به ترتيب اولويتبندى مؤلفههاى مديريت استعداد را دارا مى باشند.

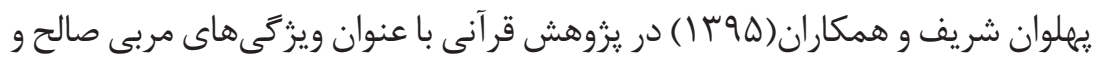
مديريت استعدادها به بيان ويزگَىهاى مربى صالح و يرورش يرداختند. ويزگى هاى مربى 
$V T-91$

صالح در قرآن با توجه به ابعاد اعتقادى، اخلاقى، نتيجهَر ايى، روشــمندى و شخصيتى عبارت است از: صبر، علاقه به سايرين، خيرخواهى، انذار با استفاده از تجربه كذشتخان، مسئوليت اجتماعى، رشديافته بودن، صراحت بيان.... . اين ويزگَىها در به كار گيرى افراد باستعداد نقش بسزايى دارد. احمدى جشــفقانى و رفيعيان (هوس () در مقاله خود با عنوان مديريت اســتعداد جشم|ندازى جديد در مديريت منابع انسانى، با تكيه بر ديدگاه اسلام و اسناد بالا دستى ايران بيان كرد كه مديريت استعداد ضرورتى است براى رسيدن به الگوى ايرانى اسلامى ييشرفته. وى در اين يزوهش يكى از ويزَّى هاى مديران را توسعه و رشد افراد زيرمجموعه

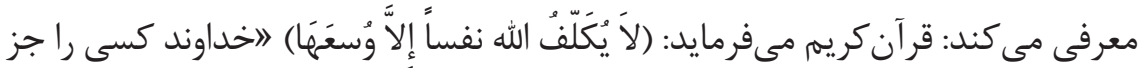
به اندازه توانايىاش تكليف نمى كنده (بقره \&^؟). مديرانى كه اختيار كافى به همكاران خويش ميى دهند و زنجيرهاى حساسيت را گسسته و از مراقبتهاى بازدارنده و نيشدار كــهه بيانكًر عدم اطمينان اســت صرفنظر مى كنـند و ميدان را براى ظهور اســـعدادها و شــكوفايـى انديشـــهـا باز مى حذارند در حالى كه نظارت حكيمانــهـ بر كارها دارند، در زمينههاى موردنظر، نخســت اختيار و آزادى مناســب را مىدهند و سيس مسئوليت مناسب را مى خواهند. هارون، محمود و اوتمــن (Harun, Mahmood, Othman, 2020) مؤلفههاى مديريت استعداد را در يزوهش خود كه در جامعه معلمان متوسطه اول انجام شده بود و به رابطه آن با رهبرى معلم در كلاس يرداخته بود معرفى كردند. يثوهش فوق در مالزى و مدارس متوسطه اول انجام شد كه س FVY نفر از معلمان به يرسشنامه ياسخ دادند. پس از تحليل دادها مؤلفههاى مديريت استعداد شناسايى و جذب استعداد، توسعه استعداد و فرهنَ استعداد شناسايى شد كه با رهبرى اثربخش معلمان ارتباط معنادار دارد. همــزه و شــمسالدين (Hamzah, Shamsudin. 2019) در يزوهش خود به مديريت استعداد و توسعه و رشد فرد مستعد در نقش معلمى در دبيرستانهاى مالزى يرداخت. نتايج يزوهش و يافتهها از مدارس نشان داد كه مؤلفههاى مديريت استعداد شامل جذب و شناســايى، انتخاب، توسعه و نكمداشـت مىباشد كه توجه به توسعه معلمان منجر به رهبرى و مديريت كلاس قوى معلمان مىشود و با آن عملكرد مدارس ارتقاء مىيابد. توسعه

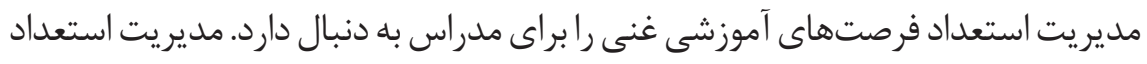


معلمان و بهرهورى در مدارس متوســـه دوم عنــــوان يثروهش (Smart \& Ebong, 2019) بود. يس از جمعآورى و تحليل دادهها، يافتهها نشان داد كه ملاحظات سياسى، ديد كاههاى دولت و عدم مشــار كت مديران در نحَهداشــت معلمان اثر زيادى بر نحَهداشت معلمان و بهروزوى دارد. همجنين نتايج نشان داد كه در فرايند مديريت استعداد نگَداشت معلمان و فراهم كردن شرايط، نقش مهمى در ماند براساس آنجه مطرح گرديد، همه مؤلفههاى شاخص و با اهميت مديريت استعداد در

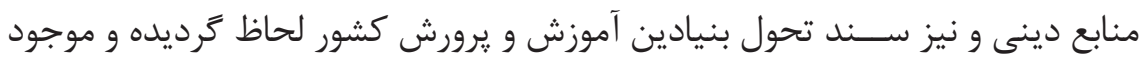

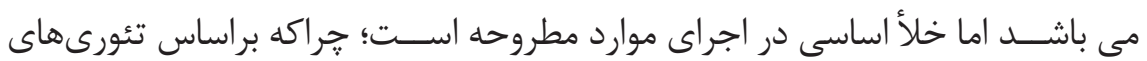
تصميمزيــرى، بهترين اهداف و طرحها اتر به مرحله اجرا نرســـد بيهوده بوده و ثمرى در يى نخواهد داشــت. دراين زمينه داشــتن نكاه جدى تر و الزام به برقرارى يك نظام اثربخش و كار آمد منابع انســانى براساس معيارهاى اســلامى و با استفاده از يك مدل مديريت استعداد براساس شرايط حال حاضر كشور، مى تواند راهَشا باشد. بخش ديخرى از خلاهاى موجود در مديريت اســتعداد منابع انسانى نيز به عدم وجود برنامهريزىهاى صحيح و مبتكرانه در جهت توسعه و حفظ و نگَداشت نيروهاى مستعد و توانمند مربوط مىشود كه در اين زمينه نيز استفاده از مدل مديريت استعداد، اثربخش خواهد بود. لذا از آنجا كه آموزش و يرورش و بهطور اخص دوره ابتدايى نقش كليدى در توسعه و رشد انســانها و كشور داشته و استقرار مديريت استعداد با به كارگيرى نخبعًان و بسترسازى آنى مناســب، نه تنها به رشـــد و تعالى شــخصى آنان كمكى مى نمايد، بلكه باعث افزايش بهرهورى مدارس گرديده و اثرات مثبت آن در كليه اركان جامعه نمود ييدا خواهد كرد و نيز بهدليل تأكيد بر محقق شدن اهداف عملياتى سند تحول آموزش و يرورش، از سوى مي ديخًر يافته يزوهشخر مبنى بر عدم انجام يروهش كافى در زمينه مديريت استعداد معلمان با اســتفاده از مدل اصلى مديريت اســتعداد (با مؤلفههاى جذب و شناســــيـ، انتخاب، به كاركيرى، توسعه و نخهداشت)، مىطلبد تا يزوهشى با رويكرد قياسى در زمينـ تدوين

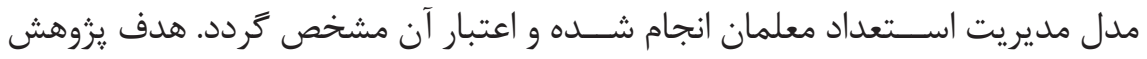
حاضر تدوين و اعتباريابى مدل مديريت اســتعداد معلمان دوره ابتدايى در نظام تعليم و تربيت عمومى و رسمى ايران مى باشد. 


\section{روش يثوهش}

روش يزوهش حاضر براساس طرح تركيبى(آميخته) اكتشافى جهرت اعتباريابى مدل

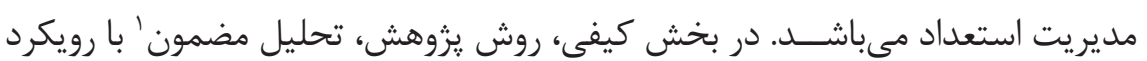
قياســى اكتشـــافى بود. جهرت كردآ ورى اطلاعات در بخش كيفى از دو روش اســـفـاده شـــد. بدينصورت كه از دو روش كتابخانهاى (مقالات، كتب، يايان نامه و اســـناد موجود

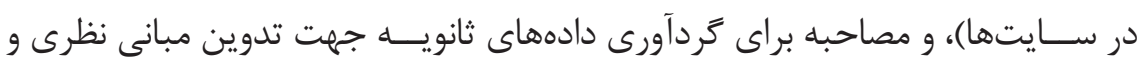
ادبيات يثروهش، و از روش تحليل مضمون با رويكرد قياســى اكتشــافى جهت استخراج مضامين و قالب مضامين در بخش كيفى يزوهش اســـفاده شد. روش يزوهش در بخش كمى توصيفى و روش گردآورى دادهها در تحقيق ييمايشى، يرسشنامه محقق ساخته اســت. يس از طراحى، يرسشنامه در اختيار افراد از طريق شبكههاى اجتماعى و پـت

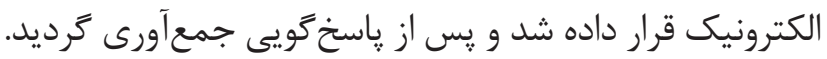

\section{جامعه، نمونه و روش نمونه}

در بخش كيفى جامعه و نمونه يزوهش برابر بودند. حوزه يزوهش ال| مورد مقالات، اســـناد و كتب مندرج در رِايكاهها، وب ســايتها، و كتابخانهها كه به تفكيك • " مقاله،

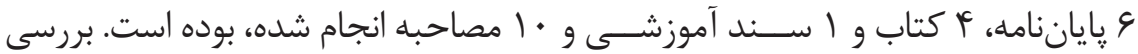
متون و مصاحبهها بهروش سرشــمارى و تعمق در كل محتواى مقالات، كتب، ســـند و

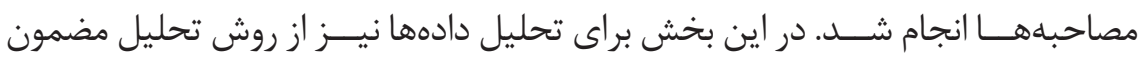
با رويكرد قياســى اكتشافى استفاده شــد. جامعه آمارى در بخش كمى كليه مديران و معاونين مدارس، كارشناسان امور يرديسها در ادارات كل آموزش و يرورش، كارشناسان آموزش و منابع انسانى ساير استانها در سراسر كشور بودند كه به گويههاى يرسشنامه

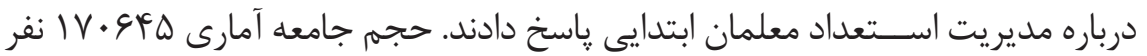
مىباشد و يثوهش در حوزه آموزش و يرورش انجام شده است. نمونه آمارى بخش كمى

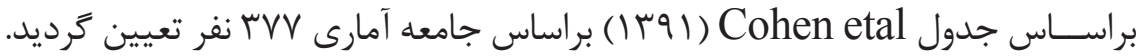
روش نمونه

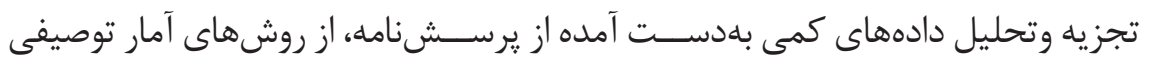




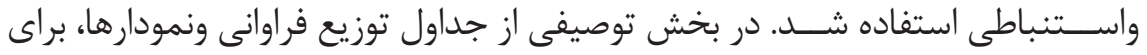

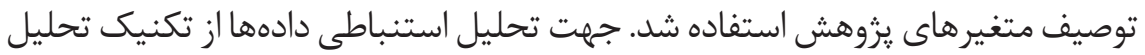

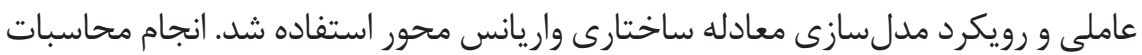
با استفاده از نسخه سب نرمافزار SPSS و Smart amos انجام شد.

\section{روايى و يايايى بخش كيفى}

يس از انجام اصلاحات بر روى مضامين، \&4 گويه براى يرسـشـنامه تدوين و تنظيم

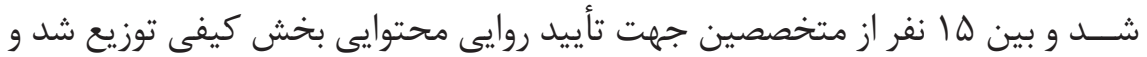

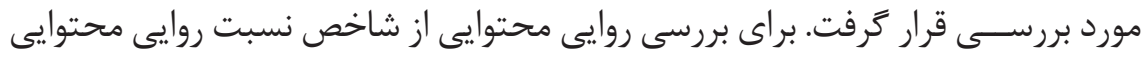

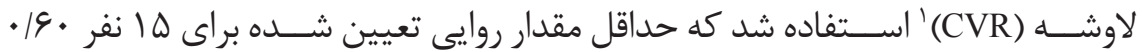

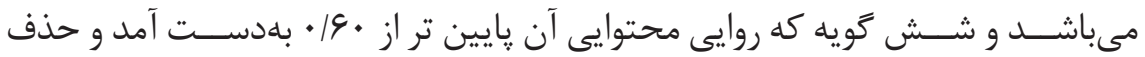
شـــجهت يايايى بخش كيفى از روش هولستى استفاده شد. پإيايى و فرمول مضامين

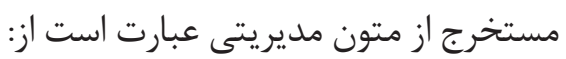

$\mathrm{Pao}=\frac{r m}{(\mathrm{n})+\mathrm{nr})}=\frac{r \times 99}{9 r+99}=\frac{19 r}{19 r}=\% 99$

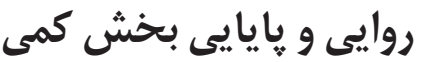

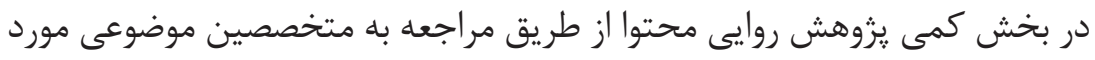

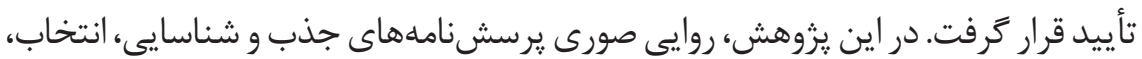

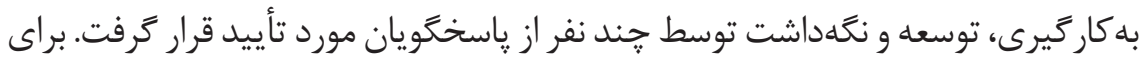

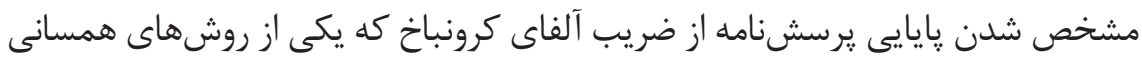

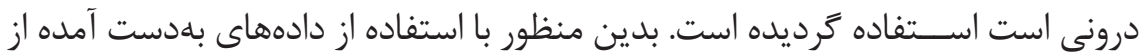

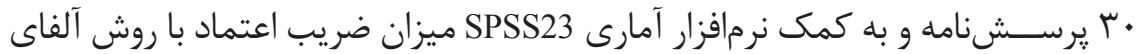

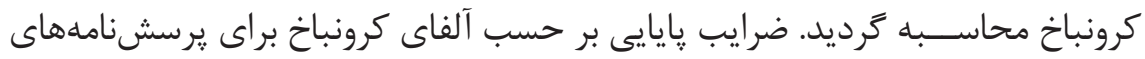

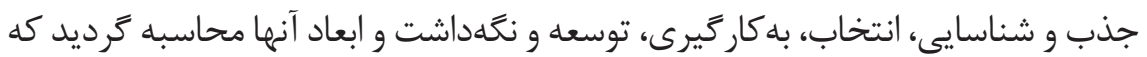

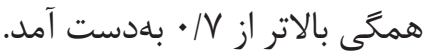


اعتبار يابى مدل مدير يت استعداد معلمان ابتدايى

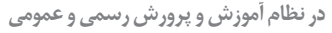

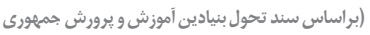

اسلامى ايران)

$v r-91$

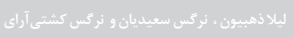

\section{يافتهها جارجوب تدوين يرسشافنه}

جدول ا. شماره تويهها براساس مضامين ثيروهش

\begin{tabular}{|c|c|c|c|}
\hline مضامين بايه & 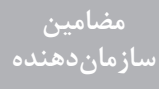 & فراتير & $\frac{1}{3^{7}}$ \\
\hline 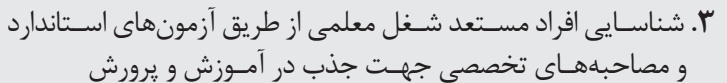 & .1 & \multirow{5}{*}{$\begin{array}{l}3 \\
3 \\
0 \\
3 \\
3\end{array}$} & \\
\hline 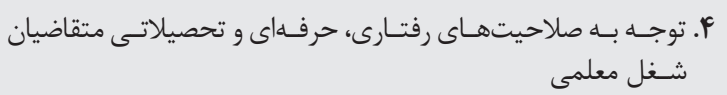 & نخبه & & \\
\hline 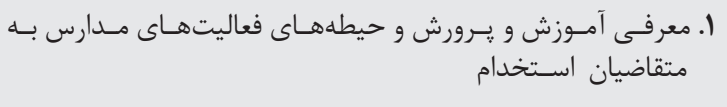 &.$r$ & & 1 \\
\hline 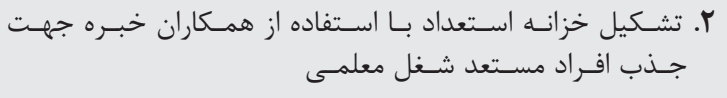 & ايجاد انغيزه & & \\
\hline 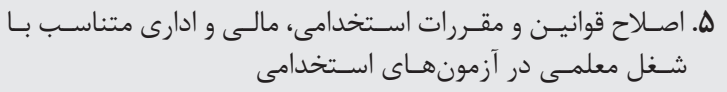 & نخبعان & & \\
\hline
\end{tabular}

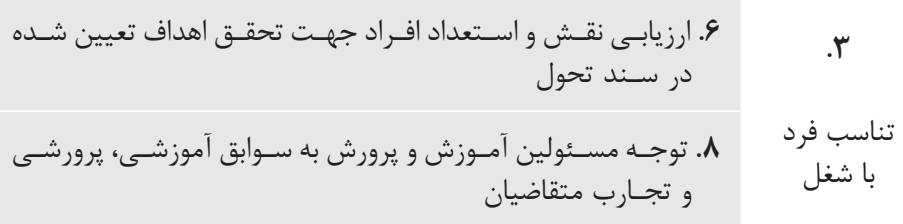

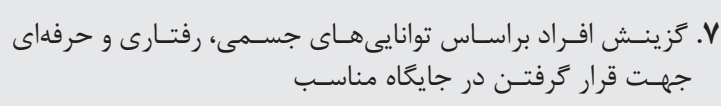

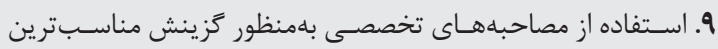

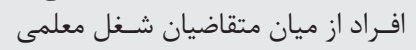

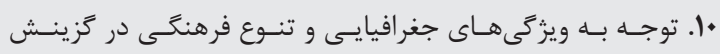
متقاضيان

Iا. اسـتفاده از نظرات معلمان پِّشكسـوت در جلســات مصاحبههاى تخصصى جهت گزينـش معلمان 


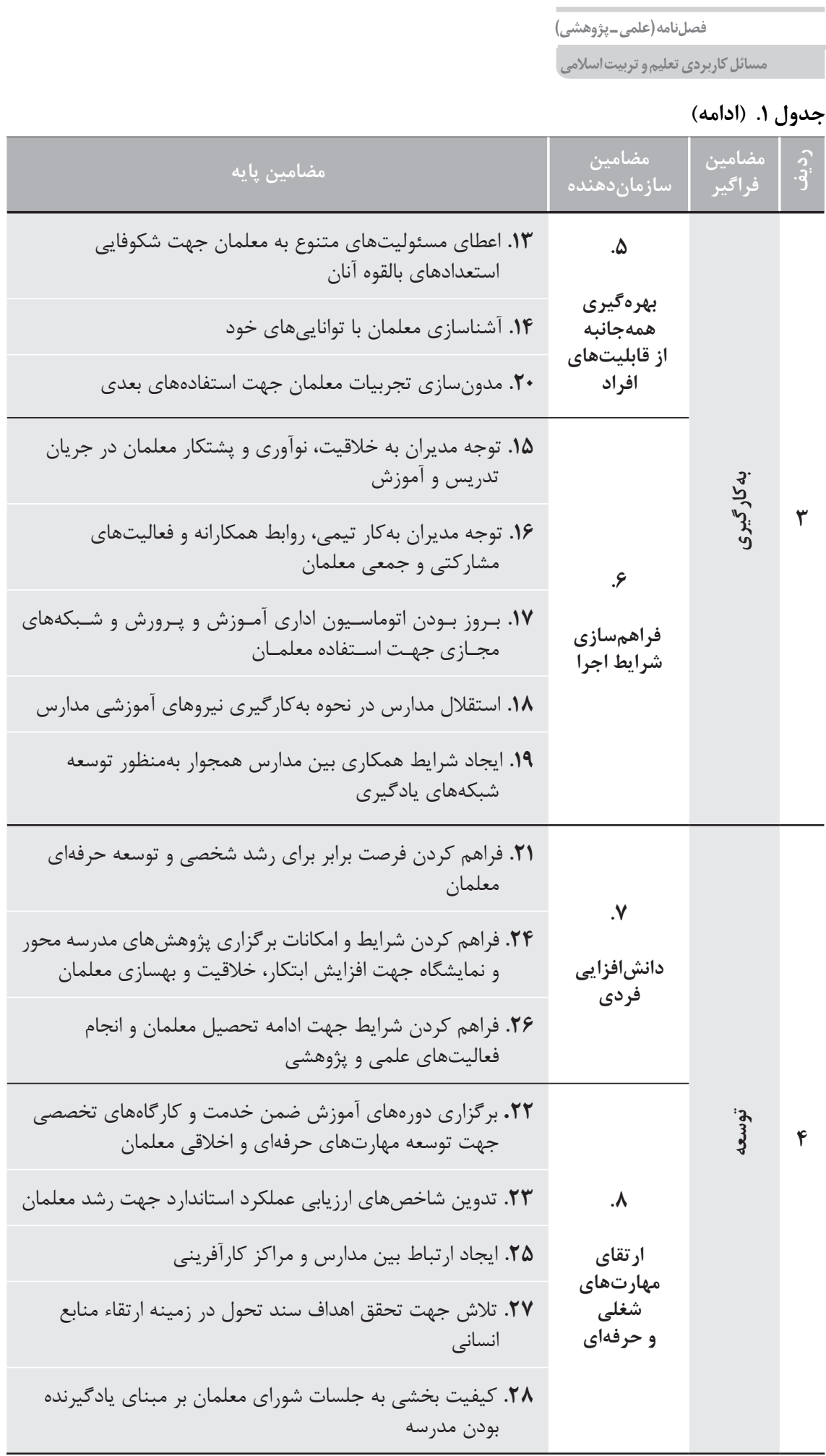


اعتبار يابى مدل مدير يت استعدادمعلمان ابتدايى

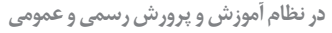

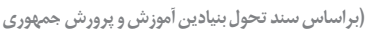

اسلامى ايران)

Vr-91

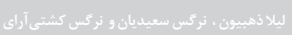

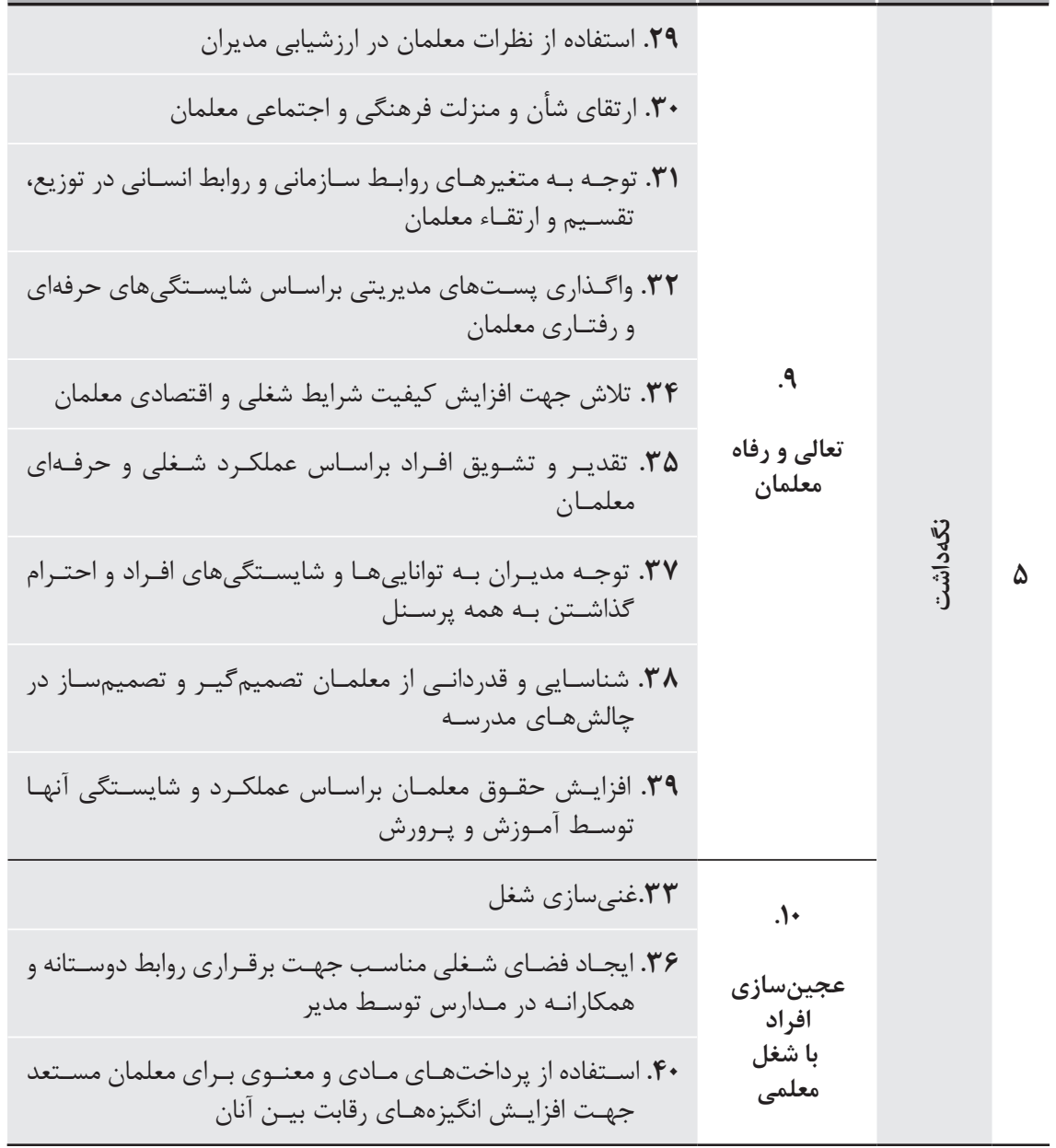

براى استخراج مضامين ابتدا متون مربوط به مديريت استعداد مطالعه گرديد سيس تعداد · f مضمون شناسايى گرديد و در نهايت ه دسته مؤلفه اصلى تحت عنوان: جذب و شناســايى (شامل شناســايى افراد نخبه و ايجاد انخيزه جهت جذب نحبعان)، انتخاب (شامل تناسب فرد با شغل و شايستهزينى)، به كارگيرى (شامل بهره

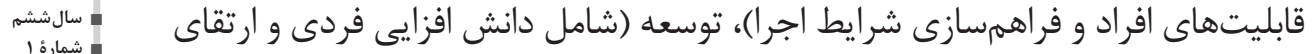
مهارتهاى شغلى و حرفهاى) و نتحداشت (شامل تعالى و رفاه معلمان و عجينسازى افراد 
با شغل معلمى) شناسايى شد كه مجموعا ه مضمون فراگير و • ( مضمون سازماندهنده

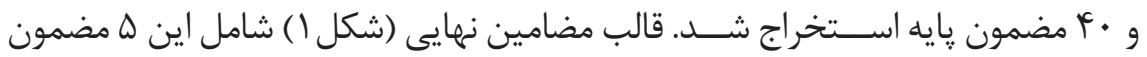
فراكير و • ا مضمون سازماندهنده بود كه در ساخت ابزار اصلى يزوهش (يرسشنامه) از اين قالب استفاده شد. ياسخ دهند مديران و معاونين مدارس ابتدايى، كارشناســان اموريرديسها در ادارات كل آموزش و يرورش، كارشناسان آموزش و منابع انسانى در ادارات آموزش و يرورش بودند. جهت روايى سازه يرسشنامه يزوهش از نرمافزار AMOS23 استفاده گرديد. همان طور كـــه از خروجى نرمافزار مشـــاهده مى گردد مدل اصلى تحليل عاملى تأييدى ارائه شــــهـ بهصورت شكل ا مىباشـــد كه در آن روابط ميان متغيرهاى آشكار(تويهها) با متغيرهاى ينهان (ابعاد مديريت اســتعداد معلمان دوره ابتدايى) و ضرائب استاندارد (بارهاى عاملى) هر كدام از مضامين ارائه شـــده اســت. همانطور كه در شكل ا مشاهده مى گر دد تمامى بارهاى عاملى ابعاد يرســشنامه بالاتر از / • بهدست آمد و مورد تأييد قرار گرفت. بارهاى عاملى همبستخى هاى متغيرها باعامل هاست. جنانجه اين همبستخَى ها بيشتر از ع| • باشند (بدون توجه به علامت منفى يا مثبت) بهعنوان بارهاى عاملى بالا و جنانجه بيشتر از س/.

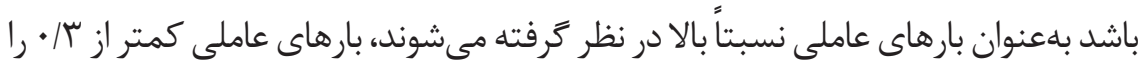

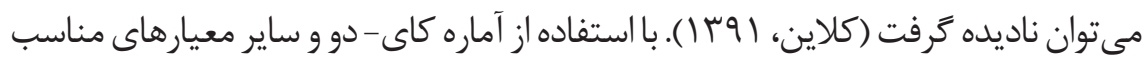
بودن برازش مدل، جدول گ شاخصهاى مناسب بودن برازش مدل تحليل عاملى تأييدى مرتبه دوم سازه مديريت استعداد معلمان دوره ابتدايى رانشان مىدهد.

\section{جدول r. بررسى بار عاملى مضامين فراتير و سازماندهنده براى مدل مديريت استعداد معلمان دوره ابتدايى بريى}

\begin{tabular}{|c|c|c|c|c|c|c|c|}
\hline نتيجه & معادارى سطح & بارعاملى & سازمان دهنين & معنادارى سطح & بارعاملى & فراتير & $\hat{3}$ \\
\hline مناسب & $\cdot 1 \cdot \cdot 1$ & $\cdot 19 \mathrm{VV}$ & شناسايى افراد نخبه & \multirow[b]{2}{*}{$\cdot 1 \cdot \cdot 1$} & \multirow[b]{2}{*}{ - IFAN } & \multirow[b]{2}{*}{ شناسايى و } & \multirow[b]{2}{*}{1} \\
\hline مناسب & $\cdot 1 \cdot \cdot 1$ & .1911 & جذباد انخيزه جهات & & & & \\
\hline مناسب & $\cdot 1 \cdot \cdot 1$ & $\cdot \mid \Delta \vee G$ & تناسب فرد با شغل & \multirow{2}{*}{$\cdot 1 \cdot \cdot 1$} & \multirow{2}{*}{ - 194q } & \multirow{2}{*}{ انتخاب } & \multirow{2}{*}{$r$} \\
\hline مناسب & $\cdot 1 \cdot \cdot 1$ &.$|9|$ & شايستهزَينى & & & & \\
\hline
\end{tabular}


اعتبار يابى مدل مدير يت استعداد معلمان ابتدايى

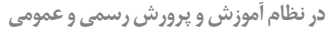

(براساس سند تحول بنيادين آموزش و يرورش جمهورى امورى

اسلامى ايران)

Vr-91

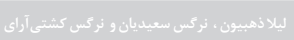

9)

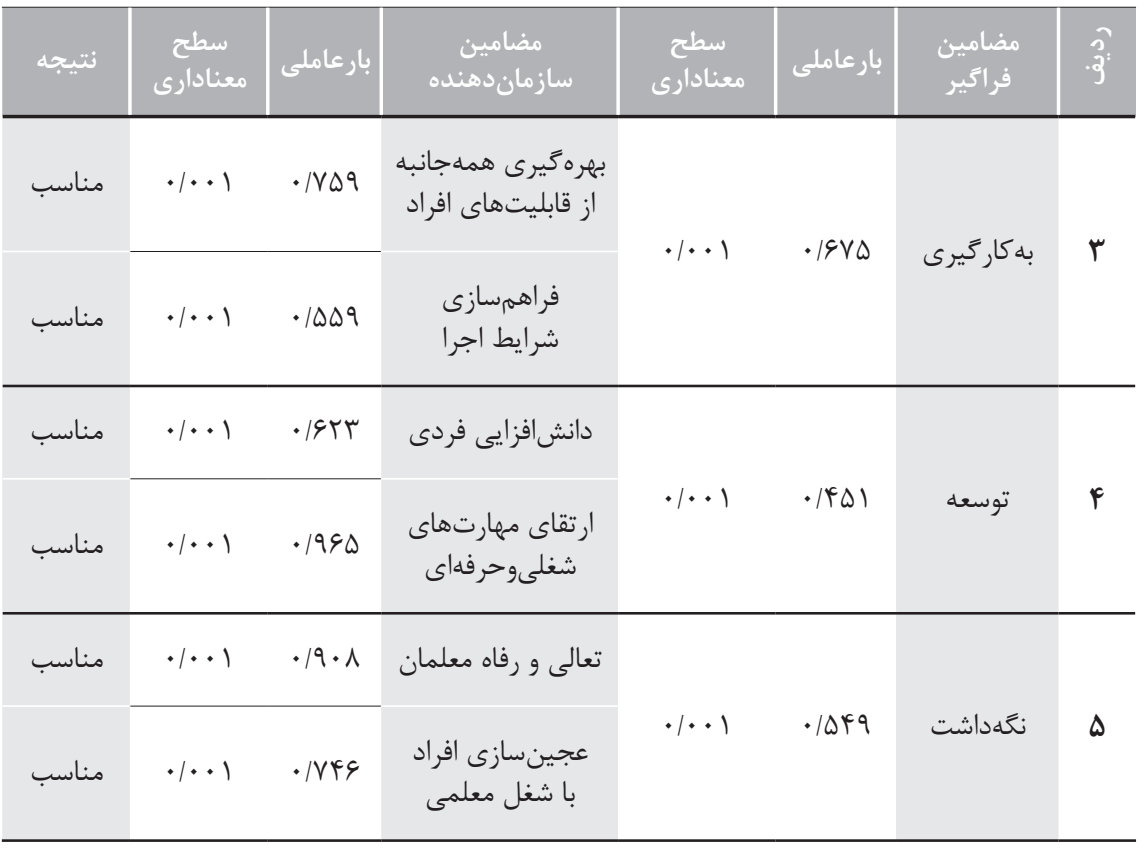

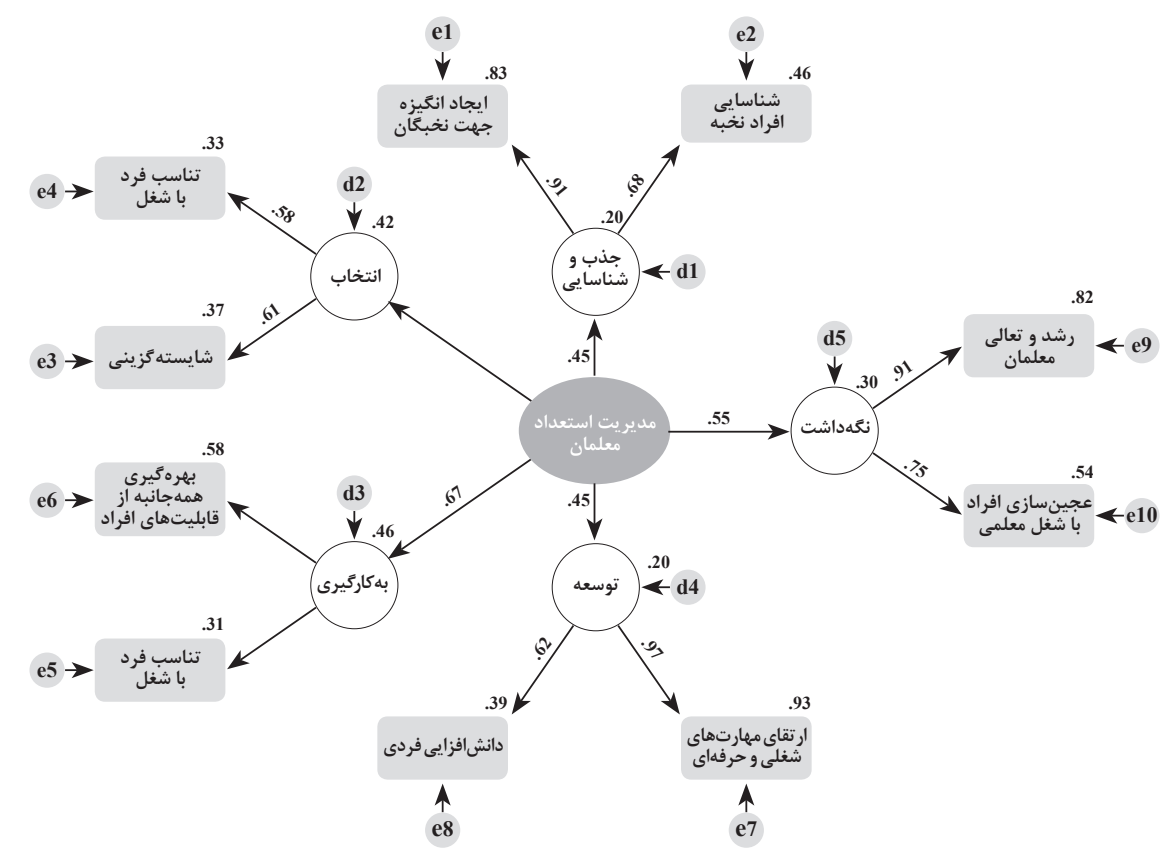

شكل ا. مدل تحليل عاملى تأييدى مر تبه دوم مدل مديريت استعداد معلمان دوره ابتدايى 


\section{نتيجهَ"يرى}

هدف يزوهش حاضر، اعتباريابى مدل مديريت استعداد معلمان ابتدايى در نظام تعليمى و تربيت رســمى و عمومى ايران بود. اطلاعات جمعآورى شده از بخشهاى كيفى و كمى، با ماتِ

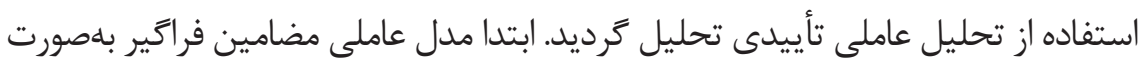
مدل عاملى ترسيهم شد كه در آن روابط ميان متغيرهاى آشكار (كويهها) با متغيرهاى ينهان (مضامين فراخير و سازماندهنده) و ضرايب استاندارد هر يك از زويهها (مضامين يايه) ارائه شــد كه با روايى بالاى بهدست آمده (بيشتر از س/ •) مدل عاملى تأييد شد. بارهاى عاملى في مضامين فراخير و سازماندهنده به ترتيب زير است:

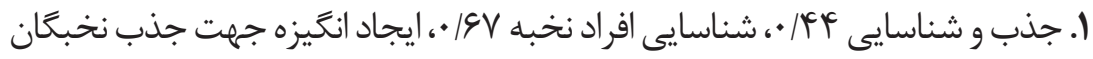

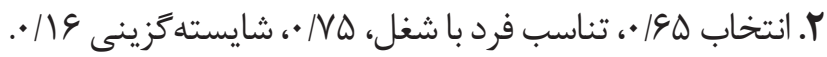

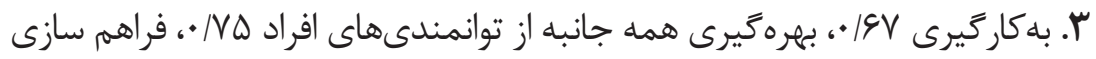

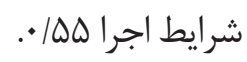

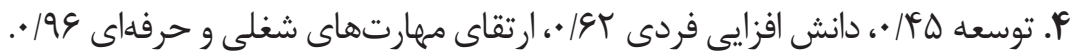

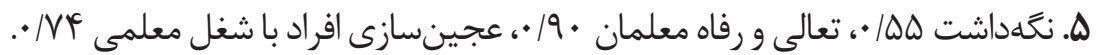
بارهاى عاملى بلدست آمده بيانگر اين نكته است كه همه مضامين فراخير و سازماندهنده

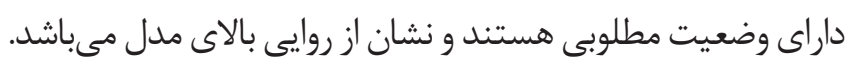

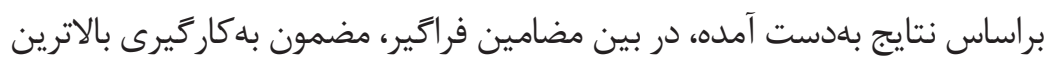

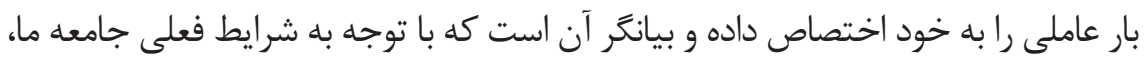

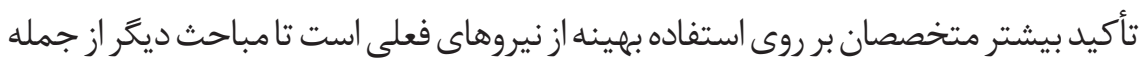
جذب استعدادها؛ در واقع به كار گيرى و نحوه توزيع استعدادها در مدارس و توجه به نقشها، شايستخى ها، خلاقيت، رفتارهاى همكارانه، ايجاد فرصت براى نيروهاى جديد، ايجاد شرايط همكارى بين مدارس و بلروزرسانى شبكههاى مجازى براى نيروها اولويت بيشترى نسبت

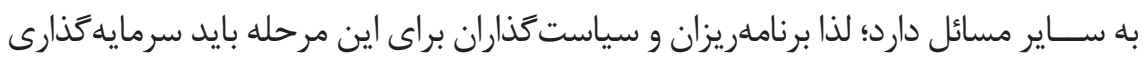

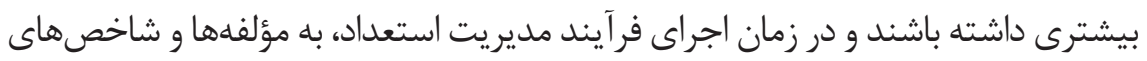
اين مضمون توجه بيشترى نمايند.

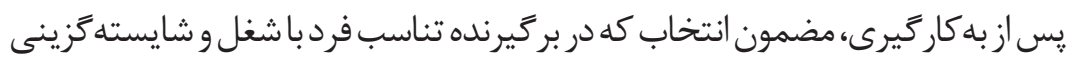

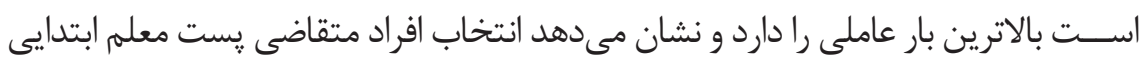


بيشـــتر از جذب و شناسايـى اهميت دارد. امام على مىفرمايند: الارززاران رااز انسانهاى باتجربه، باحياو خاندانهاى نجيب و شايسته و ييشقدم در اسلام انتخاب نما، زيرا آنها داراى اخلاق حسنه، كم طمع، نظرهايى صائب، فكرى آكاه و عاقبت انديشيندها.

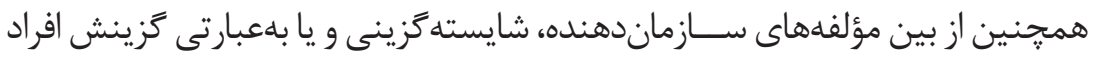
براساس توانايى ها، استفاده ازنظرات معلمان ييشكسوت، توجه به ويزگَى فرهنگى جغرافيايى،

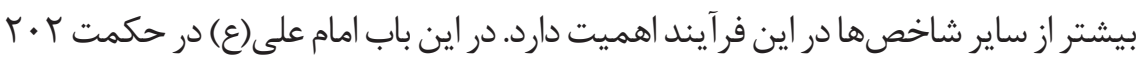
يكى از رموز توفيق را تجربه ميى داند: او من التوفيق حفظ التجربه. و يكى از عوامل موفقيت،

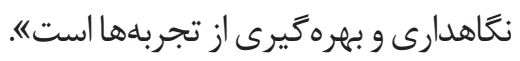

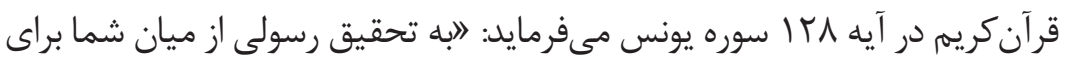

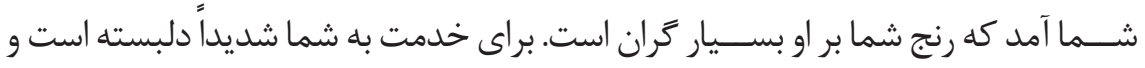

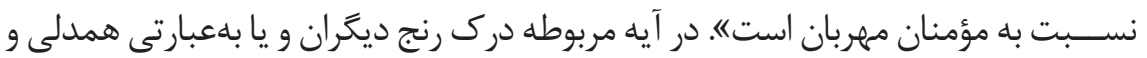
در نظر گرفتن احساس زيردستان توسط مدير مورد توجه قرار گرفته است. يس از انتخاب،

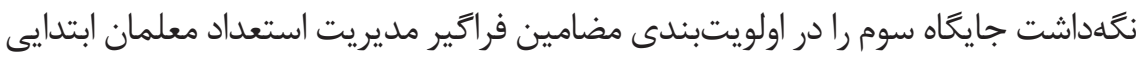
دارد؛ بعضى مواقع افراد با استعداد استخدام مىشوند اما آموزش و يرورش براى نگهداشت و ماند Fارى آنها، برنامهاى ندارد. مضمون سازمان دهنده تعالى و رفاه معلمان با بار عاملى بالا، نشان داد كه در زمينه نحهداشت معلمان، توجه به شرايط آنها، برطرف كردن نيازهايشان، توجه به افراد مستعد در زمان ارتقاء به يستهاى كليدى، توجه به توانايى آنها و قدردانى و تشويق به موقع افراد مستعد، ضرورى است و ميزان ماندكارى و با انخيزه كار كردن معلمان بوني

$$
\text { مستعد را افزايش مى دهد. }
$$

مضامين توسعه و جذب و شناسايى به ترتيب والبته تفاوت بسيار ناجيز با يكديخر، آخرين اولويت را در مدل مديريت اســتعداد معلمـــان ابتدايى به خود اختصاص دادهاند. با

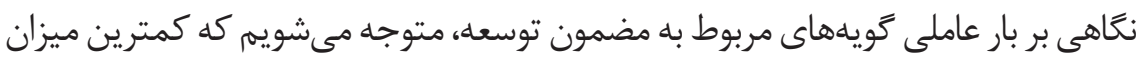

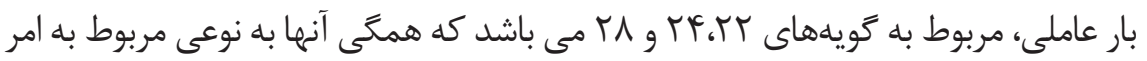

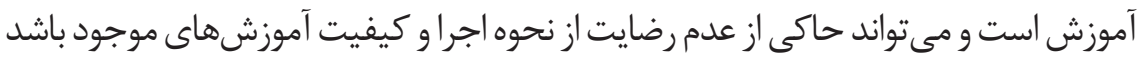
لذا بازنخرى در نيازسنجى و كيفيت آموزش هاى ضمن خدمت ضرورى است. همجنين در مرحله شناسايى و جذب، آموزش و يرورش بايد، علاوه بر اصلاح قوانين و مقررات استخدامى متناسب با شغل معلمى، به كيفيت آزمونهاى استاندارد و مصاحبه هاى تخصصى، توجه بيشترى داشته، همجنين بايد خزانه استعدادى را از افراد خبره تشكيل داده تا بتواند جذب لهب افر اد مستعد شغل معلمى را بهتر انجام دهد. مسئله جذب بايد توأم با ايدههاى نو و خلاقانه 
باشد تا افراد نخبه شخصاً تمايل به ورود در اين سيستم را داشته باشند. از بين مؤلفههاى سازماندهنده نيز دو مضمون ارتقاى مهارتهاى شغلى و حرفهاى، و و و ايجاد انگيزه جهت جذب نخبًان، بيشترين بار عاملى (به ترتيب 99/• و 19 /.) را به خود اختصاص دادهاند، همجنين از بين گويههاى يرسشنامه، گويه شماره 1 ا باعنوان استقلال

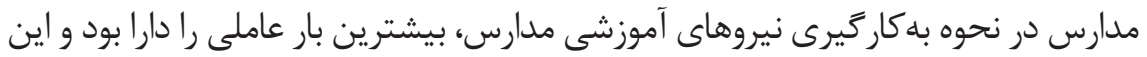

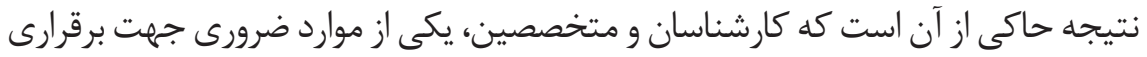
سيستم مديريت استعداد را آزادى عمل مدارس در نحوه استفاده از نيروها مى دانند بنابر اين مسئولين آموزش و يرورش بايد اين شاخصها را بيشتر از هر شاخص ديخرى در سياستها و برناملريزىهاى خود، مدنظر قرار دهند. مضمون سازماندهندهُ شناسايى افر ادنخبه بامضمون يايه توجه به صلاحيتهاى رفتارى، حرفهاى و تحصيلاتى متقاضيان شغل معلمى كهاز جمله عوامل شناخت افر ادمستعدراسنجش باست من قابليت و مهارت دانسته و نيز مضمون يايه باعنوان اصلاح قوانين و مقررات استخدامى، مالى و ادارى متناسب با شغل معلمى در آزمونهاى استخدامى، با سند تحول بنيادين آموزش و يرورش شوراى عالى انقلاب فرهنگى ( • ૧ ( ) همسو است. همجنين مضمون سازماندهنده شايسته گزينى با يزوهش نوراد صديق و همكاران (9 (1))، همخوانى دارد. بهره گيرى همه جانبه از قابليتهاى افراد شامل مضامين ثايه اعطاى مسئوليتهاى متنوع به معلمان جهرت شكوفايى استعدادهاى بالقوه آنان نيز مطابق سند تحول بنيادين آموزش و يرورش مى باشد. ديخر مضمون سازماندهنده به كار گيرى با عنوان فراهم سازى شرايط اجرا، با مضامين يايه

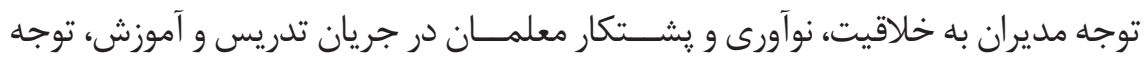

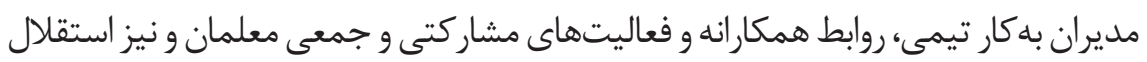

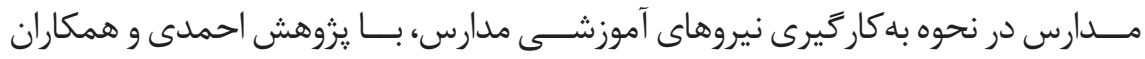
(1) (1) همسو است. دانش افزايى فردى شامل مضامين يايه فراهم كردن فرصت برابر براى رشد شخصى و توســعه حرفهاى معلمان با يزوهش (Harun, Mahmood, Othman. 2020)

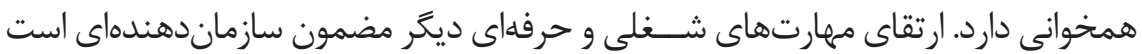

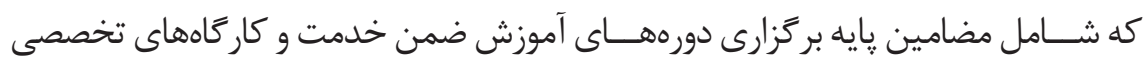

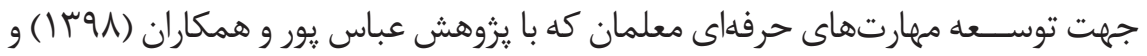

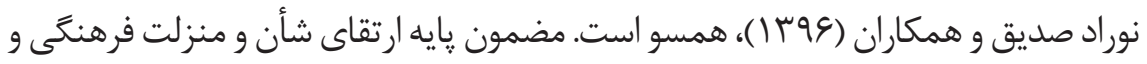
اجتماعى معلمان نيز با سند تحول آموزش و يرورش( • وس ( ) همسو مى باشد. توجه مديران به توانايى ها و شايســتخى هاى افراد و احترام حذاشـــتن به همه يرسنل با يروهش داروئيان 
vr-91

و همكاران(1) (1)، همخوانى دارد. مضمون يايه اســـفاده از يرداختهاى مادى و معنوى براى معلمان مستعد جهت افزايش انگيزههاى رقابت بين آنان با يزوهش جبارى و همكاران

همانطور كه در سند تحول بنيادين آموزش و يرورش و زيرنظامهاى مشخص شده بده بر منابع انسانى و مؤلفههاى جذب، ارتقاء، توسعه و نگَهداشت اين منابع تأكيد شده است و از آنجا كه در كشور ما آموزش و يرورش با همه اقشار جامعه در ارتباط است و بـ نوعى خروجى آن بر كل جامعه اثر زذار مى باشـــد و در معرض قضاوت عمومى اســت و مدارس خصوصاً مدارس ابتدايى از يكســـو در تبديل كردن دانشآموزان به افرادى بالنده از نظر فرهنگَى و اجتماعى نقش دارند و از سوى ديخر تامين كننده دانش عمومى مورد نياز نيروى انسانى در بخشهاى گوناگون اقتصادى اجتماعى و خدمات هستند، همين امر لزوم بر ززيدن بهترين

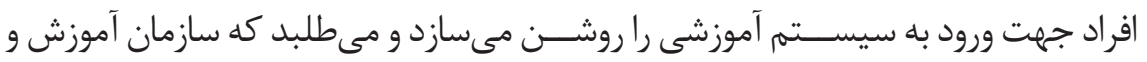
يرورش با بازنخرى در سياستها و خط مشىهاى خود، جهت تحقق اهداف عملياتى سند تحول كه نقشه راه سياست گذاران و برنامهريزان نظام تعليم و تربيت است نگاهى متفاوت به موضوع مديريت استعداد داشته باشند .

\section{يبشنهادات يزوهشى}

ييشنهاد مىشود اين :يزوهش در ديخر سازمانهاى خدماتى و آموزشى انجام شود و نتايج بررسى گردد

ييشنهاد مىشود در يثزوهشهاى آتى مدلى ارائه شود كه براى دانشآموزان (يكى ديخر از ذىنفعان اصلى در آموزش و يرورش) مؤلفههاى مربوطه شناسايى و استخراج شود. علاوه بر اين در رابطه با استخراج مؤلفههاى مديريت استعداد، بهجاى متخصصين و كارشناسان آموزشــى و مديران، از نظرات خود معلمان كه ممكن است اشراف بيشترى نسبت به ابعاد مختلف اين مسئله و نيازها و كمبودها در اين زمينه داشته باشند استفاده گردد.

\section{يبشنمهادات كاربردى}

با توجه به نتايج بهدست آمده متخصصين امر آموزش بايد به مواردى از جمله آزادى عمل مدارس ابتدايى در نحوه بلكار گيرى نيروهاى خود كه مستلزم تغيير تفكر و رويكرد آموزش و

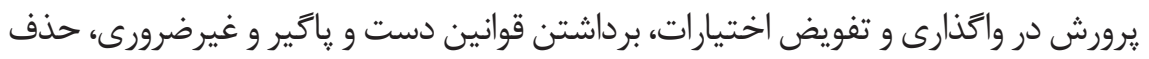
مسائل غير آموزشى از جمله مسائل سياسى و حزبى از جريان آموزش كه مى تواند در برقرارى 
سيستم مديريت استعداد مبتنى بر شايستهزَينى خدشه ايجاد نمايد، توجه به انتخاب افراد خلاق، درنظر زرفتن بحث عدالت از طريق فراهم كردن فرصت برابر براى جذب افراد مستعد، استفاده از مصاحبههاى تخصصى با كمك ييشكسوتان بهمنظور شناسايى قابليتهاى لازم جهت شغل معلمى به همراه تســهيمم دانش و ايجاد جوّ همكارى و ارتقا در صورت انتقال همه تجارب و دانش به زيردســتان بامنظور يرورش افراد شايسته جانشينى، بازنگرى در نحوه سياست گذارىها و ضمانتهاى اجرايى برنامهها و تلاش در جهت ايجاد فضاى اعتماد و اطمينان، استفاده از افراد جوان و بانشاط، آشنا به روانشناسى كودك، علاقمند به شغل معلمى و كود كان، خلاق و مبتكر در ارائه روشهاى تدريس اثربخش و ايجاد ارتباط سازنده با كود كان و خانواده ها، داراى سلامت جسمى و روانى و با تجارب آموزشى و حرفهاى مورد تأييد، تلاش جهت افزايش كيفيت شرايط شغلى و اقتصادى معلمان، تقدير و تشويق و دادن بازخورد مناســب و به موقع، توجه به شايستهسالارى و عدالت در واحذارى يستها و وبحث

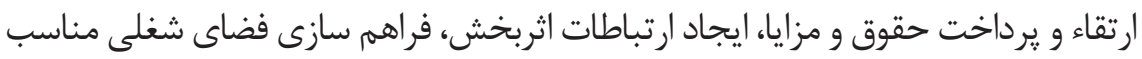
جهت ايجاد خلاقيت و رقابت سالم در بين معلمان توسط مدير، دادن استقلال و آزادى عمل

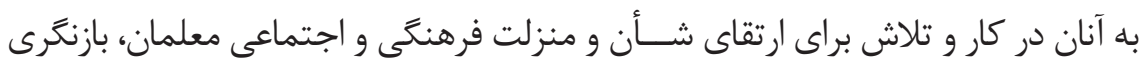
اساسى در بركزارى دورههاى ضمن خدمت و توجه بهروشهاى نو در آموزش، توجه نمايند

\section{محدوديتها}

ا. مدل ارائه شـــده براى استقرار مديريت استعداد در آموزش و يرورش مى باشد و قابل

$$
\text { تعميهم به ديخر سازمانهانيست آهـ }
$$

ז. در اين مدل ذىنفعان اصلى معلمان هســتـند و به همين دليل مدل قابل تعميهم به دانشآموزان نيست.

"ا. مدل ارائه شده با توجه به ذهنيات يزوهشخر و برداشتهاى وى از منابع علمى است.

\section{تشكّر و قدردانى}

با تشكّر و قدردانى صميمانه از متخصصين و صاحب نظران حوزه آموزش كه با شركت در مصاحبه و ارائه نظرات خود، محقق رادر رسيدن به نتايج مذكور يارى رساندند. 


\section{منابع}

$$
\text { نرآنكريم. }
$$

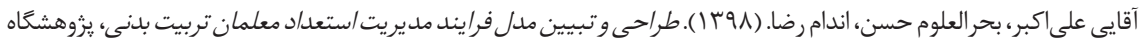
تربيت بدنى و علوم ورزشى.

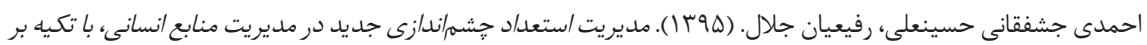

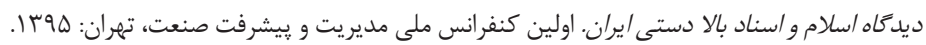

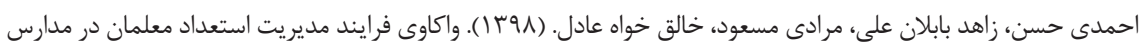

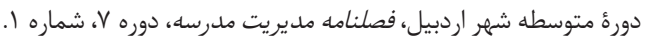

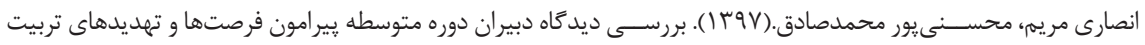

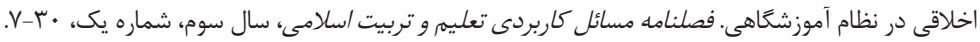

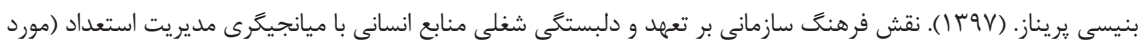

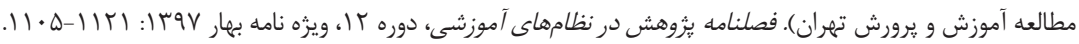

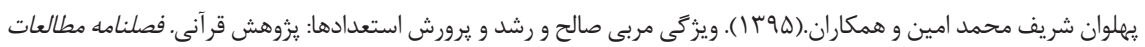

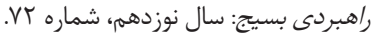

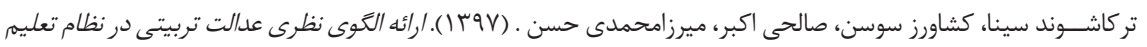

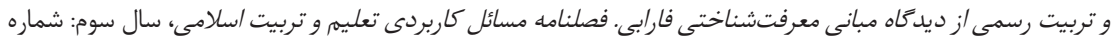
V-MF :(q)F

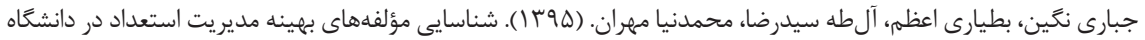

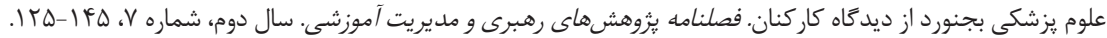

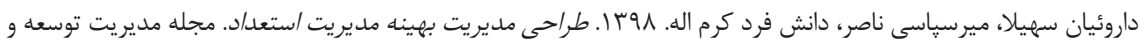

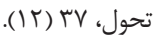
زمانى فرد زيبا، دارايى مهرى، فرح بخش ســعيد.(99 (1). طراحى مدل مديريت اســتعداد معلمان در نظام آموزش و يرورش.

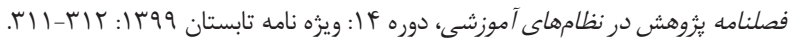

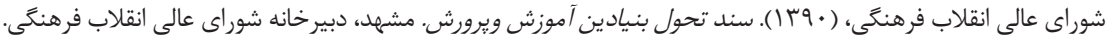

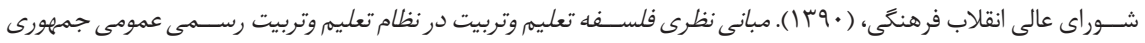
اسلامى ايران، تهران.

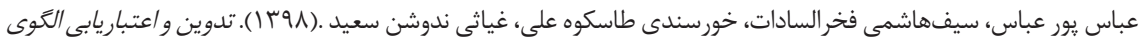

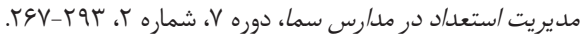

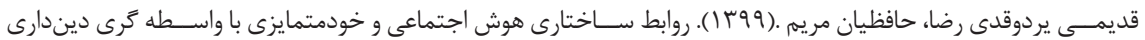

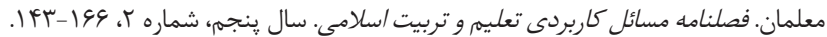

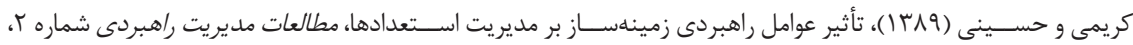

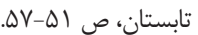

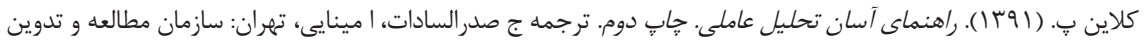

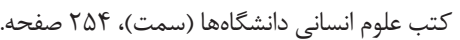
نصيرى مهدى، جهانيان رمضان. ( و ج 1 ). راهبردهاى مديريت استعداد در نظام آموزشى، فصلنامه مديريت، حسابدارى و اقتصاد، دوره r، شماره r.

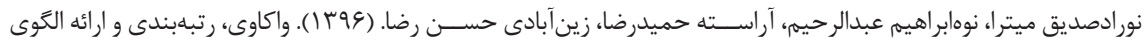

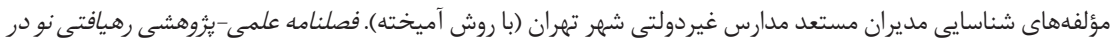




\section{REFERENCES}

Collings, D. G., \& Mellahi, K.( 2009). Strategic talent management: A review and research agenda.Human Resource Management Review, 19(4), 304-313.

Cohen LL, manion L \& Morrison S. (2000). Research methods in education by Routledge falmer,.noitide ht5.

Davies, B., \& Davies, B. J. (2010). Talent management in academies. International Journal of Educational Management, 24(5), 418-426.

Hamzah, M., Izham, M., \& Shamsudin, S.(2017). Talent Management and Teacher Leadership Talent Development in High Performing School in Malaysia. International. Journal of Educational.53-91,(1)1, secitcarP tseB

Harun N, Nik Mahmood N, Othman. (2020). The effect of talent management factors on teachers leadership at the secondary schools. Management Science Letters, 10: 225-234. Hesse-Biber, S. N., \& Yaiser, P. L. 2004. Qualitative Research. New York: Oxford.

Kehinde, J. (2012). Talent Management: Effect on Organization Performances. Journal of Management Research, 4(2). Pp. 178-186.

King, K. A., \& Vaiman, V. (2019). Enabling effective talent management through a macrocontingent approach: A framework for research and practice. BRQ Business Research Quarterly.

McDonnell, A., Collings, D. G., Mellahi, K., \& Schuler, R. 2017. Talent management: a systematic review and future prospects. European Journal of International Management, 11(1), 86-128.

Phillips, D. R., \& Roper, K. O. (2009). A framework for talent management in real estate. Journal of Corporate Real Estate, 11(1), 7-16.

Ready, D. A., \& Conger, J. A. (2007). Make your Company a Talent Factory. Harvard Business Review, .77-96.pP .(6)58

Smart F M, Ebong J M. (2019). Teachers talent management and productivity in secondary schools in Rivers State. Google scholar.com.

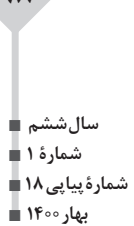

